In cooperation with the U.S. Department of Agriculture, Natural Resources Conservation Service, and the San Antonio Water System

\title{
Hydrologic and Water-Quality Data, Honey Creek State Natural Area, Comal County, Texas, August 2001-September 2003
}
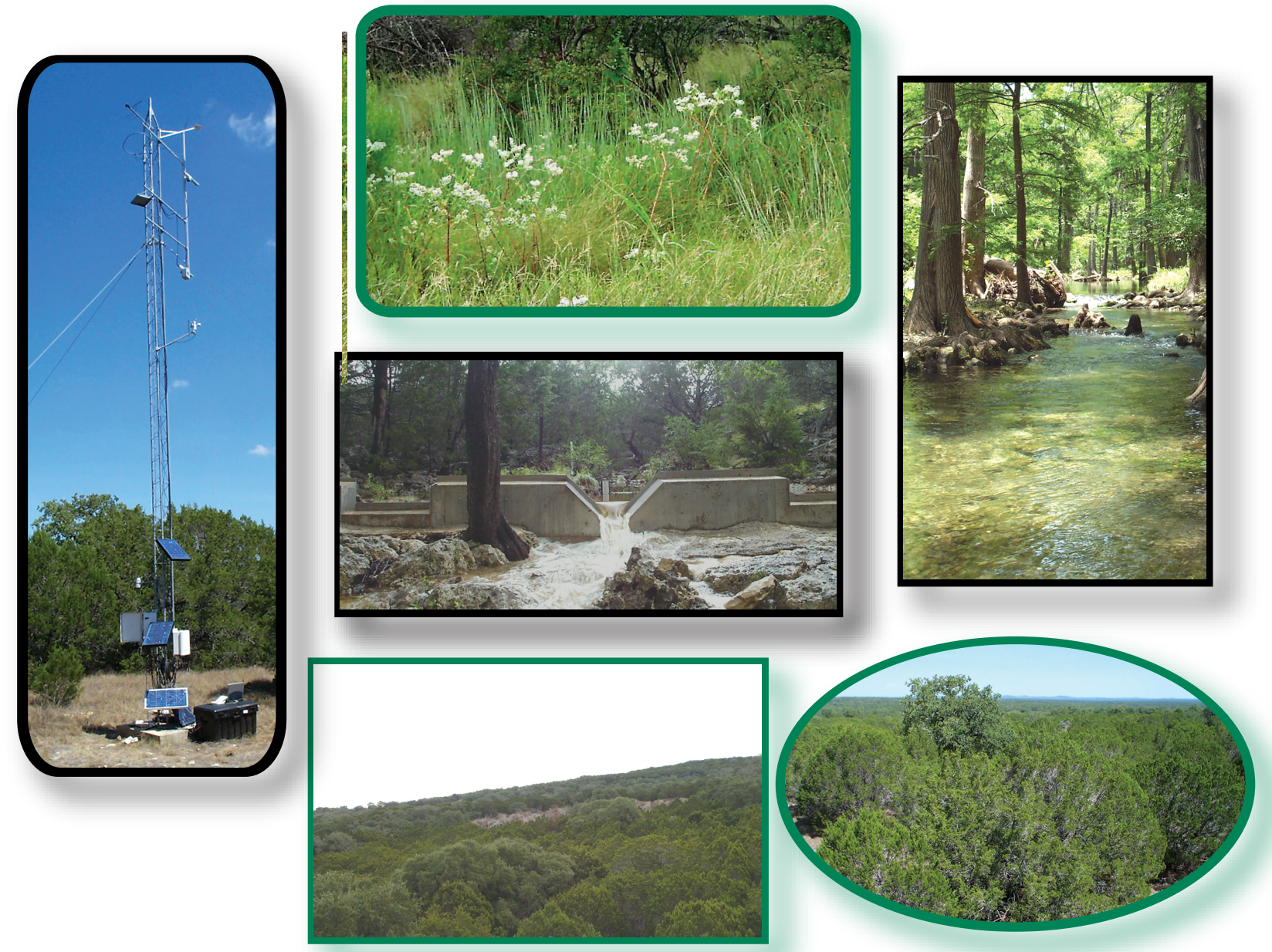

Data Series 200 
Cover.

Top left: Evapotranspiration tower in the Honey Creek State Natural Area.

Top middle: Recovery of native grasses in the Honey Creek State Natural Area.

Top right: Honey Creek in the Honey Creek State Natural Area.

Middle: Streamflow over the weir on a tributary of Honey Creek.

Bottom left and right: Predominantly ashe juniper cover with oak interspersed. 


\section{Hydrologic and Water-Quality Data, Honey Creek State Natural Area, Comal County, Texas, August 2001-September 2003}

By Richard N. Slattery, Allen L. Furlow, and Darwin J. Ockerman

In cooperation with the U.S. Department of Agriculture, Natural Resources Conservation Service, and the San Antonio Water System

Data Series 200 


\title{
U.S. Department of the Interior DIRK KEMPTHORNE, Secretary
}

\author{
U.S. Geological Survey \\ P. Patrick Leahy, Acting Director
}

\section{U.S. Geological Survey, Reston, Virginia: 2006}

For sale by U.S. Geological Survey, Information Services

Box 25286, Denver Federal Center

Denver, CO 80225

For more information about the USGS and its products:

Telephone: 1-888-ASK-USGS

World Wide Web: http://www.usgs.gov/

Any use of trade, product, or firm names in this publication is for descriptive purposes only and does not imply endorsement by the U.S. Government.

Although this report is in the public domain, permission must be secured from the individual copyright owners to reproduce any copyrighted materials contained within this report.

Suggested citation:

Slattery, R.N., Furlow, A.L., and Ockerman, D.J., 2006, Hydrologic and water-quality data, Honey Creek State Natural Area, Comal County, Texas, August 2001-September 2003: U.S. Geological Survey Data Series 200, 27 p. 


\section{Contents}

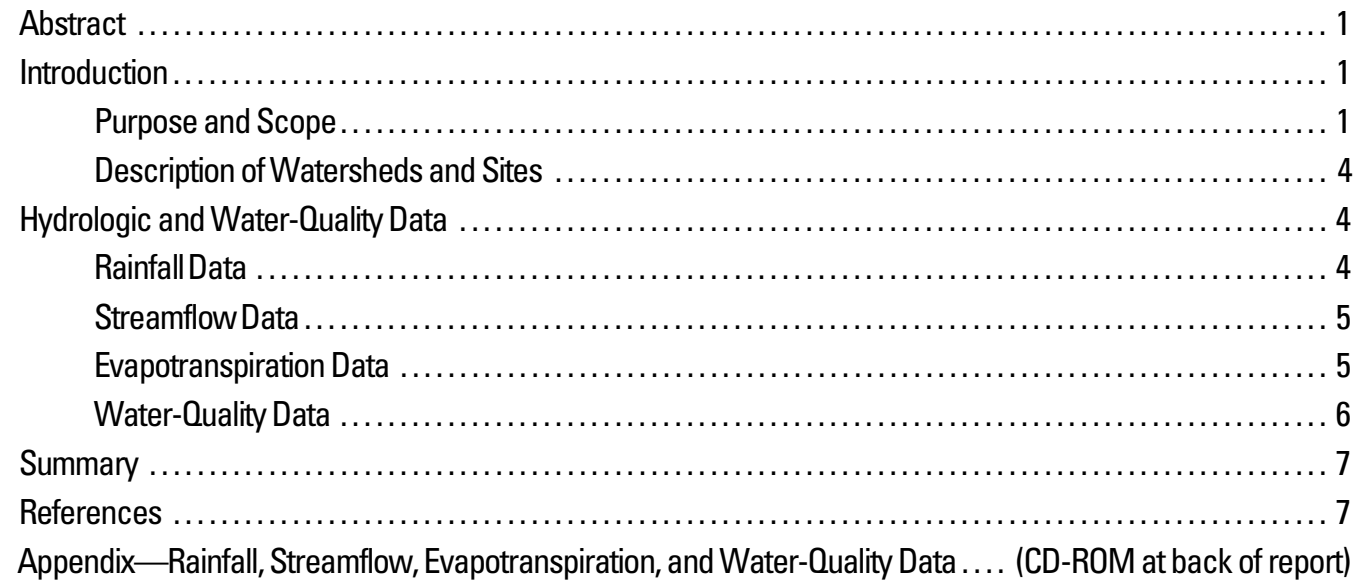

\section{Figures}

1. Map showing location of Honey Creek State Natural Area, Comal County, Texas ............... 2

2. Map showing location of data-collection sites in the Honey Creek State Natural Area,

Comal County, Texas

\section{Tables}

1. Hydrologic and water-quality data-collection sites, Honey Creek State Natural Area, Comal County, Texas

2. Daily rainfall at site 1 (USGS station 295040098283701, Honey Creek rain gage no. 1), Honey Creek State Natural Area, Comal County, Texas .............................. 9

3. Daily rainfall at site 2 (USGS station 08167347 , Unnamed tributary Honey Creek, site 1C), Honey Creek State Natural Area, Comal County, Texas ............................. 11

4. Daily rainfall at site 3 (USGS station 08167350, Unnamed tributary Honey Creek site 1T), Honey Creek State Natural Area, Comal County, Texas ............................. 13

5. Daily rainfall at site 4 (USGS station 08167353, Unnamed tributary Honey Creek Site 2T), Honey Creek State Natural Area, Comal County, Texas .............................. 15

6. Daily mean streamflow at site 2 (USGS station 08167347, Unnamed tributary Honey Creek site 1C), Honey Creek State Natural Area, Comal County, Texas

7. Daily mean streamflow at site 3 (USGS station 08167350, Unnamed tributary Honey Creek site 1T), Honey Creek State Natural Area, Comal County, Texas ........................... 19

8. Daily mean streamflow at site 4 (USGS station 08167353, Unnamed tributary Honey Creek site 2T), Honey Creek State Natural Area, Comal County, Texas .......................... 21

9. Daily evapotranspiration at site 6 (USGS station 295104098285900, Honey Creek reference evapotranspiration), Honey Creek State Natural Area, Comal County, Texas .......... 23

10. Daily evapotranspiration at site 7 (USGS station 295102098283200, Honey Creek treatment evapotranspiration), Honey Creek State Natural Area, Comal County, Texas .......... 25

11. Water-quality sample site, date, and type, Honey Creek State Natural Area, Comal County, Texas. 
Blank Page 


\title{
Hydrologic and Water-Quality Data, Honey Creek State Natural Area, Comal County, Texas, August 2001-September 2003
}

\author{
By Richard N. Slattery, Allen L. Furlow, and Darwin J. Ockerman
}

\section{Abstract}

The U.S. Geological Survey collected rainfall, streamflow, evapotranspiration, and rainfall and stormflow water-quality data from seven sites in two adjacent watersheds in the Honey Creek State Natural Area, Comal County, Texas, during August 2001-September 2003, in cooperation with the U.S. Department of Agriculture, Natural Resources Conservation Service, and the San Antonio Water System. Data collected during this period represent baseline hydrologic and water-quality conditions before proposed removal of ashe juniper (Juniperus ashei) from one of the two watersheds. Juniper removal is intended as a best-management practice to increase water quantity (aquifer recharge and streamflow) and to protect water quality. Continuous (5-minute interval) rainfall data are collected at four sites; continuous (5-minute interval) streamflow data are collected at three sites. Fifteen-minute averages of meteorological and solar-energy-related data recorded at two sites are used to compute moving 30-minute evapotranspiration values on the basis of the energy-balance Bowen ratio method. Periodic rainfall water-quality data are collected at one site and stormflow water-quality data at three sites. Daily rainfall, streamflow, and evapotranspiration totals are presented in tables; detailed data are listed in an appendix. Results of analyses of the periodic rainfall and stormflow water-quality samples collected during runoff events are summarized in the appendix; not all data types were collected at all sites nor were all data types collected during the entire 26-month period.

\section{Introduction}

The U.S. Geological Survey (USGS), in cooperation with the U.S. Department of Agriculture, Natural Resources Conservation Service, and the San Antonio Water System, began a study in 1999 to evaluate the effects of ashe juniper (Juniperus ashei) control (removal) as a best-management practice for increasing water quantity (aquifer recharge and streamflow) and protecting water quality in two watersheds in the Honey Creek State Natural Area (HCSNA) in Comal County, Tex. (fig. 1). This study is a follow-up to the Seco Creek WaterQuality Demonstration project (Seco Creek project) (Dugas and others, 1998). Results from the Seco Creek project indicate that the removal of ashe juniper trees might reduce evapotranspiration (ET) and increase water infiltration, aquifer recharge, and springflow. The current study involves the application of Seco Creek project site-specific results to a watershed scale. In one of the two watersheds, referred to as the reference watershed, ashe juniper trees are not being removed; in the adjacent watershed, referred to as the treatment watershed, ashe juniper trees are being removed. Before juniper removal, baseline rainfall, streamflow, ET, and water-quality data were collected from selected sites in the watersheds (fig. 2) during an approximately 2-year period.

\section{Purpose and Scope}

The purpose of this report is to document the baseline rainfall, streamflow, ET, and rainfall and storm-runoff (stormflow) water-quality data collected at sites in the reference and treatment watersheds in the HCSNA from August 2001 through September 2003, before juniper removal in the treatment watershed. Three sites are in the reference watershed, and four sites are in the treatment watershed; not all data types were collected at all sites nor were all data types collected during the entire 26-month period. Daily rainfall, streamflow, ET, and summaries of analyses of periodic water-quality samples are listed in tables (at end of report). Continuous (5-minute-interval) rainfall and streamflow, ET (moving 30-minute interval), and periodic rainfall and stormflow water-quality data are listed in the appendix (CD-ROM at back of report). 

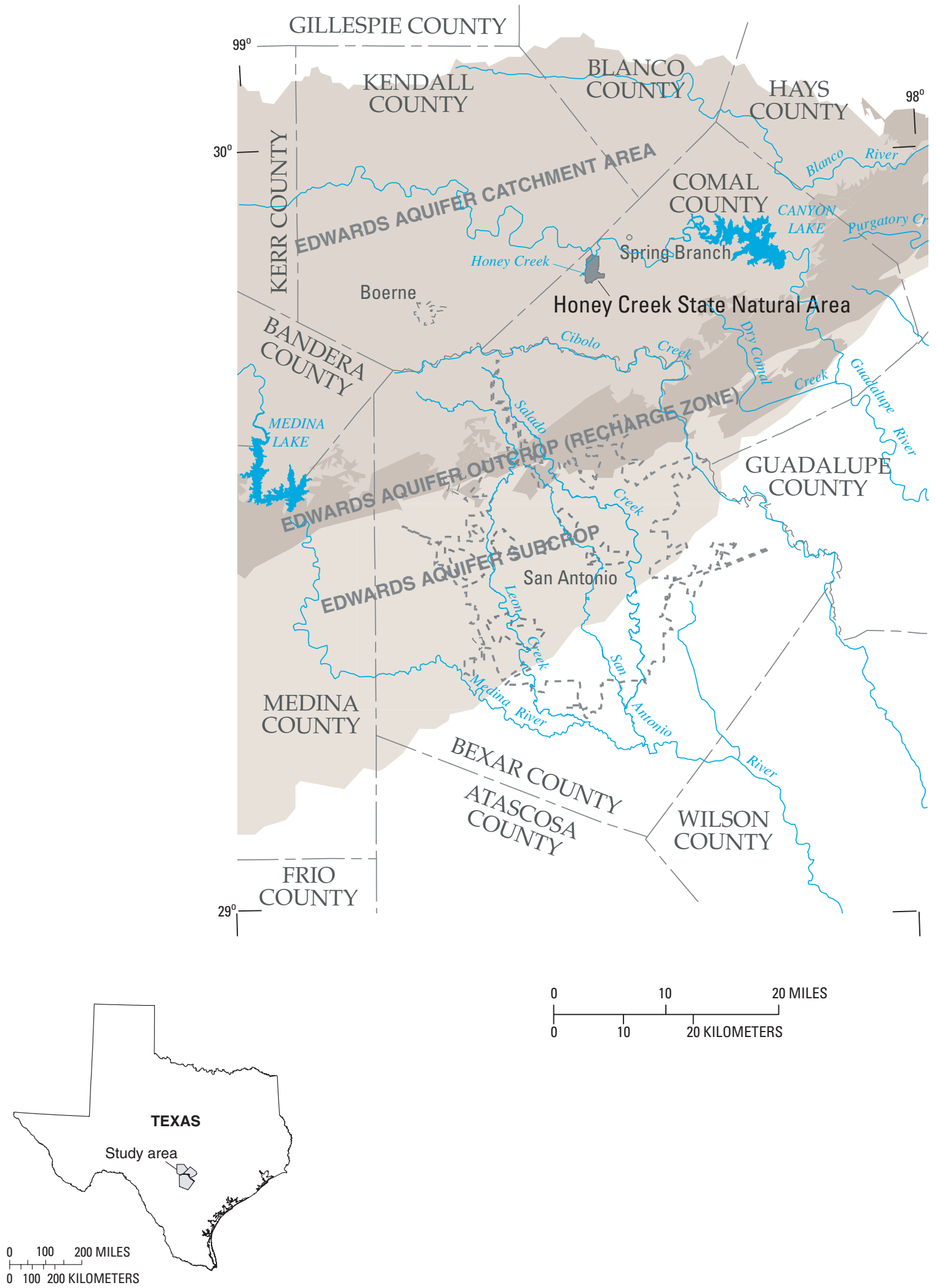

LOCATION MAP

Figure 1. Location of Honey Creek State Natural Area, Comal County, Texas. 


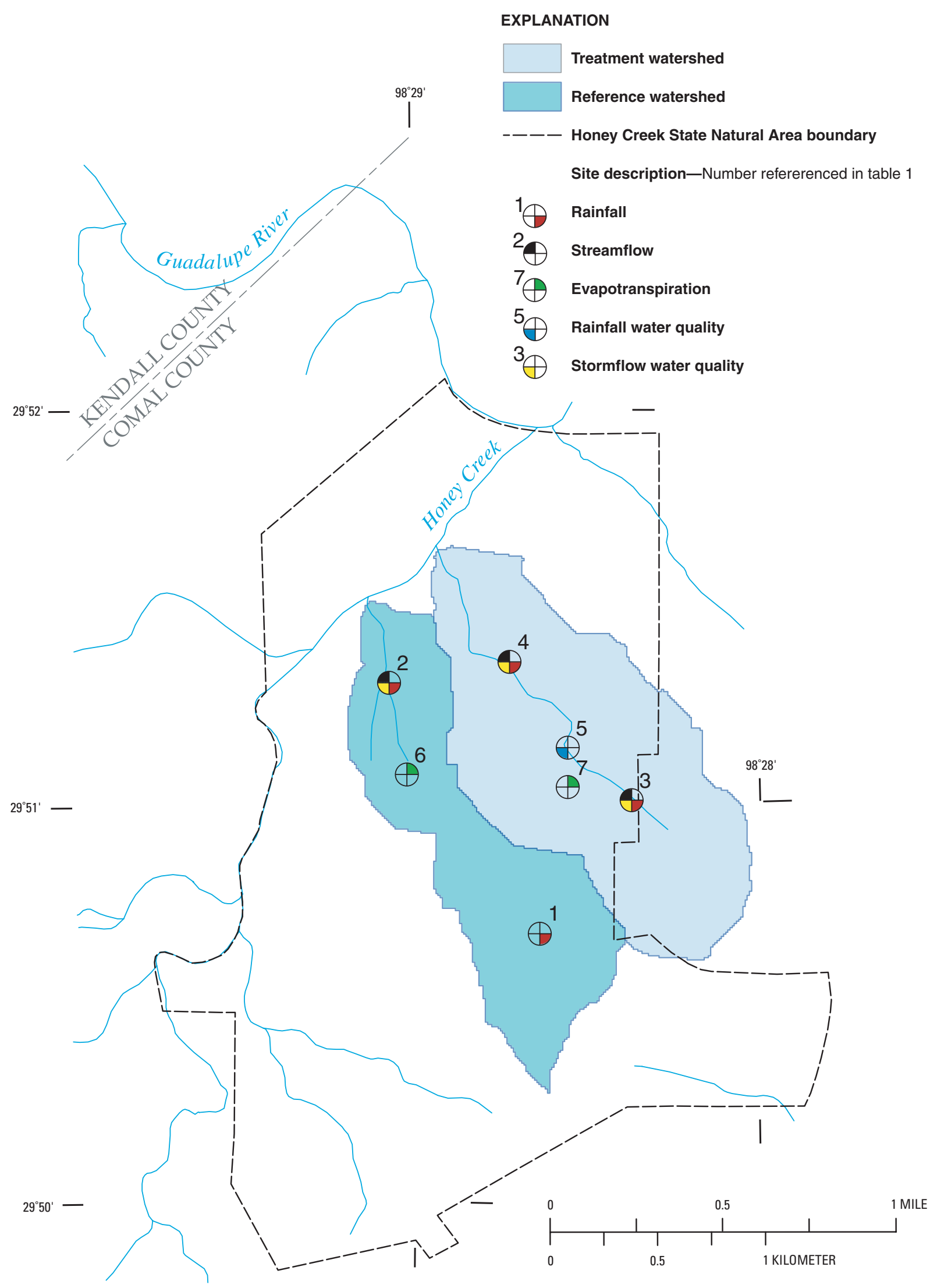

Figure 2. Location of data-collection sites in the Honey Creek State Natural Area, Comal County, Texas. 


\section{Description of Watersheds and Sites}

The two adjacent HCSNA watersheds are in the catchment area of the Edwards aquifer about 25 miles (40 kilometers) north of San Antonio (fig. 1). The catchment area, adjacent to the outcrop (recharge zone) of the Edwards aquifer to the north, comprises the upper parts of drainage basins of streams that lose water to the Edwards aquifer as the streams cross the recharge zone. The surficial geology of the watersheds primarily comprises rocks of the Lower Glen Rose Limestone, Hensel Sand, and Cow Creek Limestone of the Trinity aquifer (Ashworth, 1983). Soils generally are dark, calcareous stoney clay and clay loam with rock outcrops (U.S. Department of Agriculture, Soil Conservation Service, 1984). Vegetation consists primarily of live oak and dense ashe juniper woods with lesser stands of cedar elm, Spanish oak, and other species.

The watersheds are drained by first-order (headwater) streams that are tributaries to Honey Creek, which is a tributary to the Guadalupe River (fig. 2). The reference watershed has a drainage area of about 0.36 square mile ( 0.93 square kilometer). The treatment watershed has a drainage area of about 0.56 square mile ( 1.5 square kilometers). The upper 0.16 square mile (0.41 square kilometer) of the treatment watershed is on private land outside the HCSNA boundary.

Data-collection site number, station number, location, drainage area, type of data, and period of record are listed in table 1 . At site 1 , only rainfall in the upper part of the reference watershed is recorded (fig. 2). Streams at sites 2-4 are ephemeral and yield runoff only after heavy rainfall. At these three sites, 5-minute rainfall and streamflow data are recorded; also, periodic stormflow water-quality data are collected. Site 5 is a rainfall water-quality station. ET is monitored at sites 6 and 7 in the reference and treatment watersheds, respectively. The ET sites are in areas of relatively uniform juniper cover, wind fetch, and topography. Both ET sites record 15-minute averages of meteorological and solar-energy-related data that are used to compute moving 30-minute ET values on a 15-minute basis.

\section{Hydrologic and Water-Quality Data}

During 2000 and 2001, the USGS installed data-collection stations at the seven sites in the HCSNA (fig. 2; table 1). Rainfall data at sites 1-4 and streamflow data at sites 2-4 are transmitted every 4 hours by way of a Geostationary Operational Environmental Satellite (GOES) to the USGS National Water Information System database. ET data are retrieved from the sites during periodic station service visits. Rainfall and stormflow water-quality samples are collected as composite samples over the duration of the runoff events.

\section{Rainfall Data}

Rainfall is collected using 12-inch- (305-millimeter-) diameter tipping-bucket gages. The tipping-bucket rain gage used in this study has an accuracy of \pm 1 percent for rainfall intensities of 1 to 3 inches ( 25 to 76 millimeters) per hour, and \pm 3 percent for rainfall intensities of 0 to 1 and 3 to 6 inches ( 0 to 25 and 76 to 150 millimeters) per hour (NovaLynx Corporation, 2000). To maintain accuracy of the tipping-bucket rain gage, the instruments are periodically inspected and cleaned,

Table 1. Hydrologic and water-quality data-collection sites, Honey Creek State Natural Area, Comal County, Texas.

[Type of data: prec, continuous rainfall (5-minute data-collection interval); sf, continuous streamflow (5-minute data-collection interval); qws, periodic stormflow water quality; qwp, periodic rainfall water quality; et, evapotranspiration (30-minute data-collection interval).--, not applicable]

\begin{tabular}{|c|c|c|c|c|c|c|c|}
\hline $\begin{array}{c}\text { Site } \\
\text { no. } \\
\text { (fig. 2) }\end{array}$ & $\begin{array}{l}\text { USGS } \\
\text { station } \\
\text { no. }\end{array}$ & $\begin{array}{l}\text { Station } \\
\text { name }\end{array}$ & Latitude & Longitude & $\begin{array}{c}\text { Drainage } \\
\text { area } \\
\text { (square } \\
\text { miles) }\end{array}$ & $\begin{array}{l}\text { Type of } \\
\text { data }\end{array}$ & $\begin{array}{l}\text { Period of } \\
\text { record }\end{array}$ \\
\hline 2 & 08167347 & Unnamed tributary Honey Creek site $1 \mathrm{C}$ & $29^{\circ} 51^{\prime} 18^{\prime \prime}$ & $98^{\circ} 29^{\prime} 03^{\prime \prime}$ & 0.36 & $\begin{array}{l}\text { prec } \\
\text { sf }\end{array}$ & $\begin{array}{l}10 / 01 / 01-09 / 30 / 03 \\
10 / 01 / 01-09 / 30 / 03\end{array}$ \\
\hline 4 & 08167353 & Unnamed tributary Honey Creek site 2T & $29^{\circ} 51^{\prime} 21^{\prime \prime}$ & $98^{\circ} 28^{\prime} 42^{\prime \prime}$ & .40 & $\begin{array}{l}\text { prec } \\
\text { sf }\end{array}$ & $\begin{array}{l}10 / 01 / 01-09 / 30 / 03 \\
10 / 01 / 01-09 / 30 / 03 \\
08 / 30 / 01-06 / 30 / 02\end{array}$ \\
\hline 5 & 295108098283201 & Honey Creek rainfall water quality & $29^{\circ} 51^{\prime} 08^{\prime \prime}$ & $98^{\circ} 28^{\prime} 32^{\prime \prime}$ & -- & qwp & $10 / 11 / 02-06 / 30 / 02$ \\
\hline 7 & 295102098283200 & Honey Creek treatment evapotranspiration & $29^{\circ} 51^{\prime} 02^{\prime \prime}$ & $98^{\circ} 28^{\prime} 32^{\prime \prime}$ & .56 & et & 03/19/02-09/30/03 \\
\hline
\end{tabular}


and calibration checks are performed as described by the manufacturer. The rainfall data are processed further by eliminating values for periods of known bad record.

Daily rainfall at sites $1-4$ for water years ${ }^{1} 2002-03$ are listed in tables 2-5 (at end of report), respectively. The 5-minute rainfall data for water years 2002-03 are listed in the appendix.

\section{Streamflow Data}

Weirs constructed at sites 2-4 are used as streamflow or discharge measuring devices. Stage data recorded by pressure transducer gages are used to compute streamflow using theoretical stage-discharge relations developed for each of the weirs and calibrated using streamflow measurements across a range in stage (Bos, 1989; Hulsing, 1967). The streamflow gages are serviced periodically and crest-stage gages are used to verify recorded peak stages occurring during runoff events.

Daily mean streamflows for sites $2-4$ for water years 2002-03 are listed in tables 6-8 (at end of report), respectively. The 5-minute streamflow data for water years 2002-03 are listed in the appendix. Because of the short durations of flow at the sites, the number of discharge measurements made were insufficient to accurately calibrate the theoretical weir equations; daily mean discharges at all three sites therefore are rated only as "fair" (95 percent of the daily discharges are within 15 percent of the true discharge), and estimated daily mean discharges (daily values footnoted in tables 6 and 8 (at end of report), are rated as "poor" (daily discharges having less than "fair" accuracy) (Novak, 1985).

Total runoff at sites 2-4 for water-years 2002 and 2003 was about 135,118 , and 384 acre-feet $(0.17,0.15$, and 0.47 cubic hectometer), respectively. About 68 percent of total runoff from the watersheds (sum of runoff at sites 2 and 4 ) occurred during the period June 30-July 15, 2002.

Flow duration at sites $2-4$ is relatively short. For all runoff events occurring in water years 2002 and 2003, the maximum continuous flow duration was about 178 hours at site 2 (July 1$8,2002)$.

\section{Evapotranspiration Data}

ET from sites 6 and 7 is computed from measured properties: net radiation, soil heat flux, soil temperature, soil moisture, difference in air temperature at two different heights, and difference in air vapor pressure at the same two heights. From these data, the energy-balance Bowen ratio method is used to calculate sensible- and latent-heat fluxes (Brutsaert, 1982; Dingman, 2002; Shuttleworth, 1993). Energy balance at land surface is expressed as

$$
R-G+\Delta S=H+L E,
$$

where

$R$ is net radiation, in watts per square meter;

$G$ is soil heat flux, in watts per square meter;

$\Delta S$ is change in heat storage in the soil, in watts per square meter;

$H$ is sensible heat flux, in watts per square meter; and

$L E$ is latent heat flux, in watts per square meter.

The product $L E$ combines the latent heat of vaporization $(L)$, in joules per kilogram, and the rate of evaporation (transpiration) $(E)$, in kilograms per square meter per second.

The Bowen ratio $(B)$ is defined as the ratio between $H$ and $L E$, which, assuming equal turbulent bulk-transfer coefficients, also is expressible in terms of vertical gradients of air temperature and air vapor pressure. The equation for $B$ thus is

$$
B=H / L E=\gamma \frac{\Delta T}{\Delta e},
$$

where

$\gamma$ is the psychrometric constant, in kilopascals per degree Celsius;

$\Delta T$ is the difference in air temperature at the two heights, in degrees Celsius; and

$\Delta e$ is the difference in air vapor pressure at the two heights, in kilopascals.

$L E$ is computed by algebraic rearrangement of equations 1 and 2 :

$$
L E=\frac{R-G}{1+B} .
$$

Net radiation, $R$, is the algebraic sum of incoming and outgoing longwave (terrestrial) and shortwave (solar) radiation. A net radiometer used to measure $R$ at each site is located about 38 feet (12 meters) above land surface. When $R$ data are not available because of instrument malfunction, ET is estimated by regression using data from incoming shortwave radiation, which is measured by a pyranometer.

Soil heat flux, $G$, is estimated from three soil heat flux plates. The three flux plates are buried at a depth of about 6 inches (15 centimeters) at various exposures of shade and sun.

The change in heat storage, $\Delta S$, requires several sensors. Four soil temperature probes are placed in the soil about 2 inches (5.1 centimeters) above the heat flux plates. Two soil moisture probes are placed at about the same depth as the temperature probes. Soil moisture probes measure the volumetric water content of the soil, which is assumed to reflect the moisture content of the top 6 inches ( 15 centimeters) of soil.

The differences in air temperature and in air vapor pressure, $\Delta T$ and $\Delta e$, are computed from measurements by two aspirated air temperature and two air vapor pressure sensors; the sensors in each pair are separated vertically by about 6.5 feet ( 2.0 meters) about 22 feet ( 6.7 meters) above land surface. The positions of each sensor in the respective pairs (temperature and vapor pressure) are mechanically reversed by an automated

\footnotetext{
${ }^{1}$ A water year is the 12-month period October 1 through September 30, designated by the calendar year in which the water year ends.
} 


\section{Hydrologic and Water-Quality Data, Honey Creek State Natural Area, Comal County, Texas, August 2001-September 2003}

control system, top to bottom and bottom to top, every $15 \mathrm{~min}$ utes to compute moving average $\Delta T$ and $\Delta e$. The sensor reversal is necessary to obtain unbiased estimates of $\Delta T$ and $\Delta e$.

The properties are measured every 20 seconds, then 15 minute averages are computed and recorded by a data logger. The 15-minute averaged data are used to compute ET values using a 30-minute moving average of the Bowen ratio, $B$; a 30-minute interval for the moving average allows the temperature and vapor pressure sensors time to cycle through position reversal.

Daily ET data from sites 6 and 7 during mid-March 2002 through mid-March 2003 and during September 2003 are listed in tables 9 and 10 (at end of report), respectively. Thirty-minute ET data are listed in the appendix. ET data from sites 6 and 7 were compared for the days during which values were available from both sites. During the period March 19, 2002-September 30, 2003, data were available from both sites for 360 days. During these 360 days, total ET was 26.57 inches ( 675 millimeters) at site 6 and 27.27 inches (693 millimeters) at site 7.

\section{Water-Quality Data}

Rainfall water-quality samples are collected at site 5 and analyzed for field properties ( $\mathrm{pH}$ and specific conductance), major ions, nutrients, and the isotope ratios for hydrogen (deuterium/protium $[\delta \mathrm{D}]$ ) and for oxygen (oxygen-18/oxygen-16 $\left.\left[\delta^{18} \mathrm{O}\right]\right)$. Stormflow water-quality samples are collected at sites 2-4 and analyzed for field properties ( $\mathrm{pH}$ and specific conductance), major ions, nutrients, pesticides, the isotope ratios $\delta \mathrm{D}$ and $\delta^{18} \mathrm{O}$, and suspended sediment (concentration and sand/silt composition). Table 11 (at end of report) lists dates of runoff events and types of samples collected during 2001-02 at site 5 for rainfall water-quality analysis and at sites $2-4$ for stormflow water-quality analysis.

All water-quality samples were collected by USGS personnel. Samples are analyzed for major ions, nutrients, and pesticides by the USGS National Water Quality Laboratory (NWQL) in Denver, Colo. Major inorganic ions were analyzed using methods documented by the American Public Health Association (1998), Fishman (1993), Fishman and Friedman (1989), and Wershaw and others (1987). Nutrients were analyzed using methods documented by Fishman (1993) and Patton and Truitt (2000). Pesticides were analyzed using methods described by Furlong and others (2001), Lindley and others (1996), Madsen and others (2003), and Zaugg and others (1995).

Samples for analysis of environmental isotopes were submitted to the USGS Reston Stable Isotope Laboratory in Reston, Va. $\delta \mathrm{D}$ was analyzed using a gaseous hydrogen equilibration technique at $30{ }^{\circ} \mathrm{C}$ (Coplen and others, 1991). $\delta^{18} \mathrm{O}$ was analyzed using a carbon dioxide-water equilibration technique (Epstein and Mayeda, 1953). The hydrogen and oxygen isotopic results are reported as $\delta \mathrm{D}$ and $\delta^{18} \mathrm{O}$ (per mil) relative to the Vienna Standard Mean Ocean Water (Coplen, 1994).
Suspended sediment samples (concentration and sand/silt composition) were analyzed by the Iowa Sediment Laboratory in Iowa City, Iowa, using methods described by Guy (1969) and Matthes and others (1991).

Field data quality-assurance procedures were applied to ensure and preserve the representativeness of the waterquality samples obtained. These procedures follow the guidelines of the U.S. Geological Survey (2002), "Quality Assurance Project Plan," and the U.S. Geological Survey (variously dated), "National Field Manual for the Collection of WaterQuality Data." These procedures include adherence to sampling equipment cleaning protocols for removal of potential contaminants to the sampling equipment prior to sampling; periodic quality-assurance equipment sampling to test for possible contaminants that might bias the results of the environmental samples; and following standards for sample collection, processing, and sample holding times.

Rainfall samples are collected by an automatic sampler. When rainfall occurs, a moisture sensor activates a mechanism to uncover a clean, polyethylene collection bucket. When rainfall ends, the sampler mechanism re-covers the collection bucket to prevent evaporation and contamination of the sample. Each rainfall sample is a single composite sample representing average quality conditions during the runoff event. The samples were retrieved as soon as possible after a runoff event, chilled, and shipped overnight to the NWQL for analysis. Three composite rainfall samples were collected at site 5 during 2001-02. Results of rainfall water-quality sample analyses are listed in the appendix.

Stormflow samples also are collected by automatic samplers. The automatic samplers at each site are programmed to begin sampling when flow occurs (stage rises above the crest of the weir). At each site as many as 24 discrete samples are collected at variable time intervals during a runoff event. The discrete samples from each site are combined into a single, flowweighted composite sample for all analyses except sediment. For sediment analysis, five discrete samples that coincide with different phases of the runoff hydrograph (rising stage, rising stage mid-way to peak, peak stage, falling stage mid-way of recession after peak, and falling stage at the tail of recession) are each separately analyzed for suspended sediment concentrations and sand/silt composition. The sand/silt composition analysis yields the percentage of sediment by weight that is finer than 0.0024 inch (0.062 millimeter).

During 2001-02, 10 composite samples for constituents other than sediment were collected and analyzed from sites 2-4 (five samples for site 2, three samples for site 3, and two samples for site 4). One event-composite sample from each of the sites (August 30, 2001) was analyzed for selected pesticides. (Results indicate no detection of pesticides at or above laboratory reporting limits.) During 2001-02, 49 sediment samples were collected during runoff events from sites 2-4 (27 samples for site 2, 13 samples for site 3, and nine samples for site 4). Results of stormflow water-quality sample analyses are listed in the appendix. 


\section{Summary}

The U.S. Geological Survey, in cooperation with the U.S. Department of Agriculture, Natural Resources Conservation Service, and the San Antonio Water System, began a study in 1999 to evaluate the effects of ashe juniper (Juniperus ashei) control (removal) as a best-management practice for increasing water quantity and protecting water quality in two adjacent watersheds in the Honey Creek State Natural Area in Comal County, Tex. In one of the two watersheds, referred to as the reference watershed (drainage area about 0.36 square mile [0.93 square kilometer]), ashe juniper trees are not being removed; in the adjacent watershed, referred to as the treatment watershed (drainage area about 0.56 square mile [1.5 square kilometers]), ashe juniper trees are being removed. Before juniper removal, baseline rainfall data, streamflow data, ET data, rainfall waterquality data (field properties, major ions, nutrients, and the isotope ratios $\delta \mathrm{D}$ and $\delta^{18} \mathrm{O}$ ), and stormflow water-quality data (field properties, major ions, nutrients, pesticides, the isotope ratios $\delta \mathrm{D}$ and $\delta^{18} \mathrm{O}$, and suspended sediment) were collected from seven sites in the watersheds during the approximately 2year period from August 2001 through September 2003; not all data types were collected at all sites nor were all data types collected during the entire 26-month period.

Continuous (5-minute interval) rainfall data are collected using 12-inch- (305-millimeter-) diameter tipping-bucket gages at four sites; continuous (5-minute interval) streamflow data are collected (measured using weirs and a stage-discharge relation developed for each weir) at three sites. Fifteen-minute averages of meteorological and solar-energy-related data recorded at two sites are used to compute 30-minute ET values on the basis of the energy-balance Bowen ratio. Periodic rainfall water-quality data are collected at one site and stormflow water-quality data at three sites. Daily rainfall, streamflow, and ET totals are presented in tables; detailed data are listed in an appendix. Results of analyses of the periodic rainfall and stormflow water-quality samples collected during runoff events are summarized in the appendix.

\section{References}

American Public Health Association, 1998, Standard methods for the examination of water and wastewater (20th ed.): Washington, D.C., American Public Health Association, American Water Works Association, and Water Environment Federation, 1,220 p.

Ashworth, J.B., 1983, Ground-water availability of the Lower Cretaceous Formations in the Hill Country of south-central Texas: Texas Department of Water Resources Report 273, $173 \mathrm{p}$.

Bos, M.G., ed., 1989, Discharge measurement structures (3d ed.): The Netherlands, International Institute for Land Reclamation and Improvement, 390 p.
Brutsaert, Wilfried, 1982, Evaporation into the atmosphereTheory, history, applications: Dordrecht, Holland, D. Reidel Publishing Co., 299 p.

Coplen, T.B., 1994, Reporting of stable hydrogen, carbon, and oxygen isotopic abundances: Pure and Applied Chemistry, v. 66 , no. 2 , p. 273-276.

Coplen, T.B., Wildman, J.D., and Chen, J, 1991, Improvements in the gaseous hydrogen-water equilibration technique for hydrogen isotope-ratio analysis: Analytical Chemistry, v. 63, p. 910-912.

Dingman, S.L., 2002, Physical hydrology (2d ed.): Upper Saddle River, N.J., Prentice-Hall, 646 p.

Dugas, W.A., Hicks, R.A., and Wright, P., 1998, Effect of removal of Juniperus ashei on evapotranspiration and runoff in the Seco Creek watershed: Water Resources Research, v. 34, no. 6, p. 1,499-1,506.

Epstein, S. and Mayeda, T., 1953, Variation of O-18 content of water from natural sources: Geochimica Cosmochimica Acta, v. 4, p. 213-224.

Fishman, M.J., ed., 1993, Methods of analysis by the U.S. Geological Survey National Water Quality Laboratory-Determination of inorganic and organic constituents in water and fluvial sediments: U.S. Geological Survey Open-File Report 93-125, $217 \mathrm{p}$.

Fishman, M.J., and Friedman, L.C., eds., 1989, Methods for determination of inorganic substances in water and fluvial sediments: U.S. Geological Survey Techniques of WaterResources Investigations, book 5, chap. A1, 545 p.

Furlong, E.T., Anderson, B.D., Werner, S.L., Soliven, P.P., Coffey, L.J., and Burkhardt, M.R., 2001, Methods of analysis by the U.S. Geological Survey National Water Quality Laboratory-Determination of pesticides in water by graphitized carbon-based solid-phase extraction and highperformance liquid chromatography/mass spectrometry: U.S. Geological Survey Water-Resources Investigations Report 01-4134, 73 p.

Guy, H.P., 1969, Laboratory theory and methods for sediment analysis: U.S. Geological Survey Techniques of WaterResources Investigations, book 5, chap. C1, p.58.

Hulsing, Harry, 1967, Measurement of peak discharge at dams by indirect methods: U.S. Geological Survey Techniques of Water-Resources Investigations, book 3, chap. A5, 29 p.

Lindley, C.E., Stewart, J.T., and Sandstrom, M.W., 1996, Determination of low concentrations of acetochlor in water by automated solid-phase extraction and gas chromatography with mass selective detection: Journal of Association of Official Analytical Chemists, v. 79, no. 4, p. 962-966.

Madsen, J.F., Sandstrom, M.W., and Zaugg, S.D., 2003, Methods of analysis by the U.S. Geological Survey National Water Quality Laboratory-A method supplement for the determination of fipronil and degradates in water by gas chromatography/mass spectrometry: U.S. Geological Survey Open-File Report 02-462, 11 p.

Matthes, W.J., Jr., Sholar, C.J., and George, J.R., 1992 [1991], Quality-assurance plan for analysis of fluvial sediment by 
laboratories of the U.S. Geological Survey: U.S. Geological Survey Open-File Report 91-467, 31 p.

Novak, C.E., 1985, WRD data reports preparation guide: U.S. Geological Survey Open-File Report 85-480, 331 p.

NovaLynx Corporation, 2000, Model 260-2500 and 260-2500-12 tipping bucket rain gauge user's manual: Auburn, Calif., 14 p.

Patton, C.J., and Truitt, E.P., 2000, Methods of analysis by the U.S. Geological Survey National Water Quality Laboratory-Determination of ammonium plus organic nitrogen by a Kjeldahl digestion method and an automated photometric finish that includes digest cleanup by gas diffusion: U.S. Geological Survey Open-File Report 00-170, 31 p.

Shuttleworth, W.J., 1993, Chapter 4-Evaporation, in Maidment, D.R., ed., Handbook of hydrology: New York, McGraw-Hill p. 4.1-4.53.

U.S. Department of Agriculture, Soil Conservation Service [currently (2006) Natural Resources Conservation Service], 1984, Soil survey of Comal and Hays Counties, Texas: 21 p., sheet number 57 .
U.S. Geological Survey, 2002, Quality assurance project plan-Water quality data collection activities in the Texas District: Austin, Tex., 101 p.

U.S. Geological Survey, variously dated, National field manual for the collection of water-quality data: U.S. Geological Survey Techniques of Water-Resources Investigations, book 9, chaps. A1-A9, available online at http://pubs.water.usgs.gov/twri9A.

Wershaw, R.L., Fishman, M.J., Grabbe, R.R., and Lowe, L.E., eds., 1987, Methods for the determination of organic substances in water and fluvial sediments: U.S. Geological Survey Techniques of Water-Resources Investigations, book 5, chap. A3, $80 \mathrm{p}$.

Zaugg, S.D., Sandstrom, M.W., Smith, S.G., and Fehlberg, K.M., 1995, Methods of analysis by the U.S. Geological Survey National Water Quality Laboratory-Determination of pesticides in water by $\mathrm{C}-18$ solid-phase extraction and capillary-column gas chromatography/mass spectrometry with selected-ion monitoring: U.S. Geological Survey OpenFile Report 95-181, 60 p. 
Table 2. Daily rainfall at site 1 (USGS station 295040098283701, Honey Creek rain gage no. 1), Honey Creek State Natural Area, Comal County, Texas.

[In inches; --, not collected or computed]

\begin{tabular}{|c|c|c|c|c|c|c|c|c|c|c|c|c|}
\hline \multicolumn{13}{|c|}{ Water year October 2001 to September 2002 daily values } \\
\hline Day & Oct. & Nov. & Dec. & Jan. & Feb. & Mar. & Apr. & May & June & July & Aug. & Sept. \\
\hline 1 & 0.02 & 0 & 0.07 & 0 & 0 & 0.04 & 0 & 0 & 0 & 5.68 & 0 & 0 \\
\hline 2 & 0 & 0 & 1.26 & 0 & 0 & .01 & 0 & 0 & 0 & 5.21 & 0 & .01 \\
\hline 3 & 0 & 0 & .07 & 0 & 0 & 0 & 0 & 0 & 0 & 2.62 & 0 & 0 \\
\hline 4 & 0 & 0 & 0 & .03 & .01 & 0 & 0 & 0 & 0 & 1.57 & 0 & 0 \\
\hline 5 & 0 & .03 & .04 & .65 & .54 & 0 & 0 & 0 & 0 & 1.81 & 0 & 0 \\
\hline 6 & 0 & 0 & 0 & 0 & 0 & 0 & .21 & 0 & 0 & 0 & 0 & 0 \\
\hline 7 & 0 & 0 & 0 & 0 & .02 & 0 & .92 & 0 & 0 & .01 & 0 & 1.80 \\
\hline 8 & 0 & 0 & 1.69 & 0 & -- & .01 & .06 & 0 & 0 & .07 & .36 & .42 \\
\hline 9 & .05 & .17 & 0 & 0 & -- & 0 & 0 & 0 & 0 & .36 & 0 & .51 \\
\hline 10 & 0 & 0 & 0 & 0 & -- & 0 & 0 & 0 & 0 & 0 & .34 & .01 \\
\hline 11 & -- & 0 & .51 & 0 & -- & 0 & 0 & 0 & 0 & .02 & 0 & 0 \\
\hline 12 & -- & 0 & .01 & 0 & -- & 0 & 0 & -- & 0 & .30 & 0 & 0 \\
\hline 13 & -- & 0 & .02 & 0 & -- & 0 & 0 & -- & 0 & .19 & 0 & 0 \\
\hline 14 & 0 & .61 & 0 & 0 & -- & 0 & 0 & -- & 0 & 1.36 & 0 & 0 \\
\hline 15 & 0 & 6.47 & .17 & 0 & -- & 0 & 0 & 0 & .08 & .36 & 0 & .15 \\
\hline 16 & 0 & 0 & .03 & 0 & 0 & 0 & .11 & 0 & 0 & .10 & 0 & .01 \\
\hline 17 & 0 & .11 & 0 & 0 & 0 & 0 & 0 & 0 & 0 & .38 & 0 & 0 \\
\hline 18 & 0 & 0 & 0 & 0 & 0 & .04 & 0 & 0 & 0 & 0 & 0 & 0 \\
\hline 19 & 0 & .07 & 0 & .01 & .06 & .55 & 0 & 0 & 0 & 0 & 0 & 1.13 \\
\hline 20 & 0 & 0 & 0 & 0 & 0 & .03 & 0 & 0 & 0 & 0 & 0 & 0 \\
\hline 21 & 0 & 0 & 0 & 0 & 0 & 0 & 0 & 0 & 0 & 0 & 0 & 0 \\
\hline 22 & 0 & 0 & .02 & 0 & 0 & 0 & 0 & 0 & 0 & 0 & 0 & 0 \\
\hline 23 & 0 & 0 & 0 & 0 & 0 & 0 & 0 & 0 & 0 & 0 & 0 & 0 \\
\hline 24 & 0 & 0 & 0 & .19 & 0 & 0 & 0 & 0 & 0 & 0 & 0 & 0 \\
\hline 25 & 0 & 0 & 0 & 0 & 0 & 0 & .01 & -- & 0 & 0 & 0 & 0 \\
\hline 26 & 0 & 0 & 0 & 0 & 0 & 0 & .01 & -- & 0 & 0 & 0 & 0 \\
\hline 27 & 0 & 0 & 0 & 0 & 0 & 0 & 0 & -- & 0 & 0 & 0 & 0 \\
\hline 28 & 0 & .05 & 0 & 0 & 0 & 0 & 0 & -- & 0 & 0 & 0 & 0 \\
\hline 29 & 0 & .03 & 0 & 0 & -- & 0 & 0 & -- & .27 & 0 & .16 & 0 \\
\hline 30 & 0 & 0 & 0 & 0 & -- & .34 & 0 & 0 & 4.19 & 0 & 0 & 0 \\
\hline 31 & 0 & -- & 0 & .11 & -- & 0 & -- & 0 & -- & 0 & 0 & -- \\
\hline Total & -- & 7.54 & 3.89 & .99 & -- & 1.02 & 1.32 & -- & 4.54 & 20.04 & .86 & 4.04 \\
\hline
\end{tabular}


Table 2. Daily rainfall at site 1 (USGS station 295040098283701, Honey Creek rain gage no. 1), Honey Creek State Natural Area, Comal County, Texas-Continued.

Water year October 2002 to September 2003 daily values

\begin{tabular}{|c|c|c|c|c|c|c|c|c|c|c|c|c|}
\hline Day & Oct. & Nov. & Dec. & Jan. & Feb. & Mar. & Apr. & May & June & July & Aug. & Sept \\
\hline 1 & 0 & -- & -- & -- & -- & 0.04 & 0 & 0 & 0 & 0 & 0 & 0 \\
\hline 2 & 0 & -- & -- & -- & -- & .05 & 0 & 0 & .78 & 0 & 0 & 0 \\
\hline 3 & 0 & -- & -- & -- & -- & .10 & 0 & 0 & 0 & 0 & 0 & 0 \\
\hline 4 & 0 & -- & -- & -- & -- & 0 & 0 & 0 & 1.16 & 0 & 0 & 0 \\
\hline 5 & 0 & -- & -- & -- & -- & .02 & 0 & 0 & 1.61 & -- & 0 & 0 \\
\hline 6 & 0 & -- & -- & -- & -- & 0 & .02 & .01 & .04 & -- & 0 & 0 \\
\hline 7 & .49 & -- & -- & -- & -- & 0 & 0 & 0 & 0 & -- & 0 & 0 \\
\hline 8 & 1.80 & -- & -- & -- & -- & 0 & 0 & 0 & 0 & -- & 0 & 0 \\
\hline 9 & .35 & -- & -- & -- & -- & .01 & 0 & 0 & 0 & -- & 0 & 0 \\
\hline 10 & .04 & -- & -- & -- & -- & 0 & 0 & 0 & .41 & -- & .19 & 0 \\
\hline 11 & .01 & -- & -- & -- & -- & .04 & 0 & 0 & 0 & .01 & .06 & 1.20 \\
\hline 12 & 0 & -- & -- & -- & -- & .03 & 0 & 0 & 0 & 0 & .36 & .50 \\
\hline 13 & -- & -- & -- & -- & -- & .01 & 0 & 0 & -- & 0 & 0 & 0 \\
\hline 14 & -- & -- & -- & -- & -- & 0 & 0 & 0 & -- & 0 & 0 & .40 \\
\hline 15 & -- & -- & -- & -- & -- & 0 & 0 & 0 & .66 & .11 & 0 & 0 \\
\hline 16 & -- & -- & -- & -- & -- & 0 & 0 & 0 & 0 & .43 & 0 & 0 \\
\hline 17 & -- & -- & -- & -- & -- & .01 & 0 & 0 & 0 & 0 & 0 & .01 \\
\hline 18 & -- & -- & -- & -- & -- & .15 & 0 & 0 & 0 & 0 & 0 & .36 \\
\hline 19 & -- & -- & -- & -- & -- & 0 & 0 & 0 & 0 & 0 & 0 & .01 \\
\hline 20 & -- & -- & -- & -- & -- & 0 & 0 & 0 & 0 & 0 & 0 & .31 \\
\hline 21 & -- & -- & -- & -- & -- & 0 & 0 & 0 & 0 & 0 & 0 & .78 \\
\hline 22 & -- & -- & -- & -- & -- & .17 & .12 & 0 & 0 & 0 & 0 & 0 \\
\hline 23 & -- & -- & -- & -- & -- & .01 & .04 & 0 & 0 & 0 & 0 & 0 \\
\hline 24 & -- & -- & -- & -- & -- & 0 & 0 & 0 & 0 & 0 & 0 & 0 \\
\hline 25 & -- & -- & -- & -- & -- & .09 & 0 & 0 & 0 & 0 & 0 & 0 \\
\hline 26 & -- & -- & -- & -- & -- & 0 & 0 & .01 & .37 & 0 & 0 & .22 \\
\hline 27 & -- & -- & -- & -- & -- & 0 & 0 & 0 & 0 & 0 & 0 & 0 \\
\hline 28 & -- & -- & -- & -- & 0 & 0 & 0 & 0 & .04 & 0 & 0 & 0 \\
\hline 29 & -- & -- & -- & -- & -- & 0 & 0 & 0 & 0 & 0 & 0 & 0 \\
\hline 30 & -- & -- & -- & -- & -- & 0 & 0 & 0 & 0 & 0 & 0 & 0 \\
\hline 31 & -- & -- & -- & -- & -- & 0 & -- & 0 & -- & 0 & 0 & -- \\
\hline Total & -- & -- & -- & -- & -- & .73 & .18 & .02 & -- & -- & .61 & 3.79 \\
\hline
\end{tabular}


Table 3. Daily rainfall at site 2 (USGS station 08167347, Unnamed tributary Honey Creek site 1C), Honey Creek State Natural Area, Comal County, Texas.

[In inches; --, not collected or computed]

\begin{tabular}{|c|c|c|c|c|c|c|c|c|c|c|c|c|}
\hline \multicolumn{13}{|c|}{ Water year October 2001 to September 2002 daily values } \\
\hline Day & Oct. & Nov. & Dec. & Jan. & Feb. & Mar. & Apr. & May & June & July & Aug. & Sept. \\
\hline 1 & 0 & 0 & 0.10 & 0 & 0 & 0.05 & 0 & 0 & 0 & 5.98 & 0 & 0 \\
\hline 2 & 0 & 0 & 1.23 & 0 & 0 & .01 & 0 & 0 & 0 & 5.06 & 0 & 0 \\
\hline 3 & 0 & 0 & .08 & 0 & 0 & 0 & 0 & 0 & 0 & 2.76 & 0 & 0 \\
\hline 4 & 0 & 0 & 0 & .11 & .01 & 0 & 0 & 0 & 0 & 2.00 & 0 & 0 \\
\hline 5 & 0 & 0 & 0 & .46 & .56 & 0 & 0 & 0 & .04 & 1.99 & 0 & 0 \\
\hline 6 & 0 & 0 & 0 & 0 & 0 & 0 & .24 & 0 & 0 & 0 & 0 & 0 \\
\hline 7 & 0 & 0 & 0 & 0 & .01 & 0 & .94 & 0 & 0 & .01 & 0 & 1.40 \\
\hline 8 & 0 & .02 & 1.93 & 0 & 0 & 0 & .07 & 0 & 0 & .03 & .32 & .57 \\
\hline 9 & .07 & .11 & 0 & 0 & 0 & 0 & 0 & 0 & .01 & .29 & 0 & .74 \\
\hline 10 & 0 & 0 & .01 & 0 & 0 & 0 & 0 & 0 & 0 & 0 & .75 & .01 \\
\hline 11 & 2.31 & 0 & .51 & 0 & 0 & 0 & 0 & 0 & 0 & 0 & .01 & 0 \\
\hline 12 & 1.43 & 0 & .01 & 0 & 0 & 0 & 0 & 0 & 0 & .34 & 0 & 0 \\
\hline 13 & .69 & 0 & .02 & 0 & 0 & 0 & 0 & 1.24 & 0 & .20 & 0 & 0 \\
\hline 14 & 0 & .60 & 0 & 0 & 0 & 0 & 0 & 0 & 0 & 2.00 & 0 & 0 \\
\hline 15 & 0 & 6.12 & .21 & 0 & 0 & 0 & 0 & 0 & .07 & .80 & 0 & .07 \\
\hline 16 & 0 & .03 & .03 & 0 & 0 & 0 & .09 & 0 & .09 & .11 & 0 & 0 \\
\hline 17 & 0 & .07 & 0 & 0 & 0 & 0 & 0 & .01 & 0 & .21 & 0 & 0 \\
\hline 18 & 0 & 0 & 0 & 0 & 0 & .05 & 0 & 0 & 0 & .01 & 0 & 0 \\
\hline 19 & 0 & .07 & .01 & .01 & .11 & .77 & 0 & 0 & 0 & 0 & 0 & .70 \\
\hline 20 & 0 & 0 & 0 & 0 & 0 & .03 & 0 & 0 & 0 & 0 & 0 & 0 \\
\hline 21 & 0 & 0 & 0 & 0 & 0 & 0 & 0 & 0 & 0 & 0 & 0 & 0 \\
\hline 22 & 0 & 0 & .01 & 0 & 0 & 0 & 0 & 0 & 0 & 0 & 0 & 0 \\
\hline 23 & 0 & 0 & 0 & 0 & 0 & 0 & 0 & 0 & 0 & 0 & 0 & 0 \\
\hline 24 & 0 & 0 & 0 & .29 & 0 & 0 & 0 & 0 & 0 & 0 & 0 & 0 \\
\hline 25 & 0 & 0 & .01 & 0 & 0 & 0 & .01 & 0 & 0 & 0 & 0 & 0 \\
\hline 26 & 0 & 0 & 0 & 0 & 0 & 0 & .01 & .09 & 0 & 0 & 0 & 0 \\
\hline 27 & 0 & 0 & 0 & 0 & 0 & 0 & 0 & 0 & .01 & 0 & 0 & 0 \\
\hline 28 & 0 & .17 & 0 & 0 & 0 & 0 & 0 & 1.21 & .06 & 0 & 0 & 0 \\
\hline 29 & 0 & .04 & 0 & 0 & -- & 0 & 0 & 0 & .16 & 0 & .16 & 0 \\
\hline 30 & 0 & 0 & 0 & 0 & -- & 1.62 & 0 & 0 & 3.96 & 0 & 0 & 0 \\
\hline 31 & 0 & -- & 0 & .12 & -- & 0 & -- & 0 & -- & 0 & 0 & -- \\
\hline Total & 4.50 & 7.23 & 4.16 & .99 & .69 & 2.53 & 1.36 & 2.55 & 4.40 & 21.79 & 1.24 & 3.49 \\
\hline
\end{tabular}


Table 3. Daily rainfall at site 2 (USGS station 08167347, Unnamed tributary Honey Creek site 1C), Honey Creek State Natural Area, Comal County, Texas-Continued.

Water year October 2002 to September 2003 daily values

\begin{tabular}{|c|c|c|c|c|c|c|c|c|c|c|c|c|}
\hline Day & Oct. & Nov. & Dec. & Jan. & Feb. & Mar. & Apr. & May & June & July & Aug. & Sept. \\
\hline 1 & 0.12 & 0 & 0 & 0 & 0 & 0.04 & 0 & -- & -- & 0 & -- & 0.01 \\
\hline 2 & 0 & .96 & 0 & 0 & .01 & .05 & 0 & -- & -- & .02 & -- & 0 \\
\hline 3 & 0 & .14 & .12 & 0 & 0 & .12 & 0 & -- & -- & .01 & -- & 0 \\
\hline 4 & 0 & .68 & .60 & 0 & 0 & 0 & 0 & -- & -- & -- & -- & 0 \\
\hline 5 & 0 & .01 & 0 & 0 & .12 & .03 & 0 & -- & -- & -- & 0 & .08 \\
\hline 6 & 0 & 0 & 0 & 0 & .09 & 0 & .01 & -- & -- & -- & 0 & 0 \\
\hline 7 & .43 & 0 & 0 & 0 & 0 & 0 & 0 & -- & -- & -- & 0 & 0 \\
\hline 8 & 1.78 & 0 & .62 & 0 & .16 & 0 & 0 & -- & 0 & .30 & 0 & 0 \\
\hline 9 & .46 & 0 & .81 & 0 & .02 & 0 & 0 & -- & 0 & 0 & 0 & 0 \\
\hline 10 & 0 & 0 & 0 & 0 & 0 & 0 & 0 & -- & .42 & 0 & .19 & 0 \\
\hline 11 & 0 & 0 & .01 & .07 & 0 & .06 & 0 & -- & 0 & 0 & .07 & .83 \\
\hline 12 & 0 & 0 & .55 & 1.21 & .03 & .03 & 0 & -- & 0 & 0 & .36 & .49 \\
\hline 13 & .03 & 0 & 0 & 0 & .06 & .01 & 0 & -- & 2.11 & 0 & 0 & 0 \\
\hline 14 & .12 & 0 & .01 & 0 & .03 & 0 & 0 & -- & 0 & 0 & .01 & .82 \\
\hline 15 & 0 & 0 & 0 & .01 & 0 & 0 & 0 & -- & .70 & -- & 0 & 0 \\
\hline 16 & 0 & 0 & 0 & 0 & 0 & 0 & 0 & -- & 0 & -- & 0 & 0 \\
\hline 17 & 0 & 0 & 0 & 0 & 0 & 0 & 0 & -- & 0 & -- & 0 & .01 \\
\hline 18 & .10 & 0 & 0 & 0 & 0 & .13 & 0 & -- & 0 & -- & 0 & .40 \\
\hline 19 & 1.37 & 0 & 0 & 0 & .03 & 0 & 0 & -- & 0 & -- & 0 & 0 \\
\hline 20 & .02 & 0 & 0 & 0 & 2.14 & 0 & -- & -- & 0 & -- & 0 & -- \\
\hline 21 & .03 & 0 & 0 & 0 & .27 & 0 & -- & -- & 0 & -- & 0 & -- \\
\hline 22 & .64 & 0 & .04 & 0 & 0 & .22 & -- & -- & 0 & -- & 0 & -- \\
\hline 23 & .71 & 0 & .37 & 0 & 0 & .01 & -- & -- & 0 & -- & .04 & -- \\
\hline 24 & 1.52 & 0 & 0 & 0 & .01 & 0 & 0 & -- & 0 & -- & 0 & -- \\
\hline 25 & .03 & 0 & 0 & .16 & 0 & .14 & 0 & -- & 0 & -- & 0 & -- \\
\hline 26 & .03 & 1.05 & 0 & .01 & .30 & 0 & 0 & -- & .21 & -- & 0 & -- \\
\hline 27 & .03 & 0 & .01 & 0 & 0 & 0 & 0 & -- & 0 & -- & 0 & -- \\
\hline 28 & .08 & 0 & 0 & .02 & 0 & 0 & 0 & -- & .12 & -- & 0 & -- \\
\hline 29 & .01 & 0 & .08 & .01 & -- & 0 & 0 & -- & 0 & -- & 0 & -- \\
\hline 30 & 0 & 0 & .12 & 0 & -- & 0 & 0 & -- & 0 & -- & .25 & -- \\
\hline 31 & .01 & -- & .01 & 0 & -- & 0 & -- & -- & -- & -- & .16 & -- \\
\hline Total & 7.52 & 2.84 & 3.35 & 1.49 & 3.27 & .84 & -- & -- & -- & -- & -- & -- \\
\hline
\end{tabular}


Table 4. Daily rainfall at site 3 (USGS station 08167350, Unnamed tributary Honey Creek site 1T), Honey Creek State Natural Area, Comal County, Texas.

[In inches; --, not collected or computed]

\begin{tabular}{|c|c|c|c|c|c|c|c|c|c|c|c|c|}
\hline \multicolumn{13}{|c|}{ Water year October 2001 to September 2002 daily values } \\
\hline Day & Oct. & Nov. & Dec. & Jan. & Feb. & Mar. & Apr. & May & June & July & Aug. & Sept. \\
\hline 1 & 0 & 0 & 0.01 & -- & -- & 0.04 & 0 & 0 & 0 & 6.36 & 0 & 0 \\
\hline 2 & 0 & 0 & -- & -- & -- & .02 & 0 & 0 & 0 & 5.60 & 0 & .02 \\
\hline 3 & 0 & 0 & -- & -- & -- & 0 & 0 & 0 & 0 & 2.97 & 0 & 0 \\
\hline 4 & 0 & 0 & -- & -- & -- & 0 & 0 & 0 & 0 & 1.61 & 0 & 0 \\
\hline 5 & 0 & 0 & -- & -- & -- & 0 & 0 & 0 & .01 & 2.10 & 0 & 0 \\
\hline 6 & 0 & 0 & -- & -- & -- & 0 & .25 & 0 & 0 & 0 & 0 & .02 \\
\hline 7 & 0 & 0 & -- & -- & -- & 0 & 1.29 & 0 & 0 & .05 & 0 & 2.01 \\
\hline 8 & 0 & .04 & -- & -- & -- & .02 & .08 & 0 & 0 & .06 & .40 & .52 \\
\hline 9 & .05 & .12 & -- & -- & 0 & 0 & 0 & 0 & 0 & .36 & 0 & .57 \\
\hline 10 & 0 & 0 & -- & -- & 0 & 0 & 0 & 0 & 0 & 0 & .45 & .01 \\
\hline 11 & 2.44 & 0 & -- & -- & 0 & 0 & 0 & 0 & 0 & 0 & .01 & 0 \\
\hline 12 & 1.46 & 0 & -- & -- & 0 & 0 & 0 & 0 & 0 & .19 & 0 & 0 \\
\hline 13 & .78 & 0 & -- & -- & 0 & 0 & 0 & 1.28 & 0 & .21 & 0 & 0 \\
\hline 14 & 0 & .75 & -- & -- & 0 & 0 & 0 & 0 & 0 & 1.39 & 0 & 0 \\
\hline 15 & 0 & 6.49 & -- & -- & 0 & 0 & 0 & 0 & .16 & .80 & 0 & .16 \\
\hline 16 & 0 & .02 & -- & -- & 0 & 0 & .11 & 0 & .08 & .09 & 0 & 0 \\
\hline 17 & 0 & .01 & -- & -- & 0 & 0 & 0 & .04 & 0 & .37 & 0 & .01 \\
\hline 18 & 0 & 0 & -- & -- & 0 & .05 & 0 & 0 & 0 & 0 & 0 & 0 \\
\hline 19 & 0 & 0 & -- & -- & .13 & .98 & 0 & 0 & 0 & 0 & 0 & 1.32 \\
\hline 20 & 0 & 0 & -- & -- & 0 & .03 & 0 & 0 & 0 & 0 & 0 & 0 \\
\hline 21 & 0 & 0 & -- & -- & 0 & .01 & 0 & 0 & 0 & 0 & 0 & 0 \\
\hline 22 & 0 & 0 & -- & -- & 0 & 0 & 0 & 0 & 0 & 0 & 0 & 0 \\
\hline 23 & 0 & 0 & -- & -- & 0 & 0 & 0 & 0 & 0 & 0 & 0 & 0 \\
\hline 24 & 0 & 0 & -- & -- & 0 & 0 & 0 & 0 & 0 & 0 & 0 & 0 \\
\hline 25 & 0 & 0 & -- & -- & 0 & 0 & .01 & 0 & 0 & 0 & 0 & 0 \\
\hline 26 & 0 & 0 & -- & -- & 0 & 0 & .02 & .12 & 0 & 0 & 0 & 0 \\
\hline 27 & 0 & 0 & -- & -- & 0 & 0 & 0 & 0 & .01 & 0 & 0 & 0 \\
\hline 28 & 0 & .02 & -- & -- & .01 & 0 & 0 & 1.24 & .02 & 0 & 0 & 0 \\
\hline 29 & 0 & 0 & -- & -- & -- & 0 & 0 & 0 & .18 & 0 & .15 & 0 \\
\hline 30 & 0 & 0 & -- & -- & -- & 1.50 & 0 & 0 & 4.30 & 0 & 0 & 0 \\
\hline 31 & 0 & -- & -- & -- & -- & 0 & -- & 0 & -- & 0 & 0 & -- \\
\hline Total & 4.73 & 7.45 & -- & -- & -- & 2.65 & 1.76 & 2.68 & 4.76 & 22.16 & 1.01 & 4.64 \\
\hline
\end{tabular}


Table 4. Daily rainfall at site 3 (USGS station 08167350, Unnamed tributary Honey Creek site 1T), Honey Creek State Natural Area, Comal County, Texas-Continued.

\begin{tabular}{|c|c|c|c|c|c|c|c|c|c|c|c|c|}
\hline \multicolumn{13}{|c|}{ Water year October 2002 to September 2003 daily values } \\
\hline Day & 0ct. & Nov. & Dec. & Jan. & Feb. & Mar. & Apr. & May & June & July & Aug. & Sept. \\
\hline 1 & 0.03 & 0 & 0 & 0 & 0 & 0.04 & 0 & 0 & 0 & 0 & 0 & 0.03 \\
\hline 2 & 0 & 1.13 & 0 & 0 & .02 & .05 & 0 & 0 & .83 & .02 & 0 & 0 \\
\hline 3 & 0 & .14 & .12 & 0 & 0 & .08 & 0 & 0 & 0 & 0 & 0 & 0 \\
\hline 4 & 0 & .77 & .56 & 0 & 0 & 0 & 0 & 0 & 1.38 & .32 & 0 & 0 \\
\hline 5 & 0 & 0 & 0 & 0 & .13 & .01 & 0 & 0 & 1.49 & 1.67 & 0 & .08 \\
\hline 6 & 0 & 0 & 0 & 0 & .10 & 0 & .02 & 0 & .06 & 1.53 & 0 & .01 \\
\hline 7 & .30 & 0 & 0 & 0 & 0 & 0 & 0 & .02 & 0 & .21 & 0 & 0 \\
\hline 8 & 2.72 & 0 & .77 & 0 & .19 & 0 & 0 & 0 & 0 & .29 & 0 & 0 \\
\hline 9 & .52 & 0 & .99 & 0 & .02 & 0 & 0 & 0 & 0 & 0 & 0 & 0 \\
\hline 10 & 0 & 0 & .01 & 0 & .01 & 0 & 0 & 0 & .45 & 0 & .12 & 0 \\
\hline 11 & 0 & 0 & .01 & .08 & 0 & .04 & 0 & 0 & 0 & 0 & .06 & 1.29 \\
\hline 12 & 0 & 0 & .72 & 1.37 & .04 & 0 & 0 & 0 & 0 & 0 & .29 & .48 \\
\hline 13 & .03 & 0 & 0 & 0 & .08 & .01 & 0 & 0 & 2.24 & 0 & 0 & 0 \\
\hline 14 & .13 & 0 & 0 & 0 & .03 & 0 & 0 & 0 & .01 & 0 & .08 & .12 \\
\hline 15 & 0 & 0 & 0 & .01 & 0 & 0 & 0 & 0 & .78 & .10 & 0 & 0 \\
\hline 16 & 0 & 0 & 0 & 0 & 0 & 0 & .01 & 0 & 0 & .65 & 0 & 0 \\
\hline 17 & 0 & 0 & 0 & 0 & 0 & .01 & 0 & 0 & 0 & 0 & 0 & 0 \\
\hline 18 & .10 & 0 & 0 & 0 & 0 & .14 & 0 & 0 & 0 & 0 & 0 & .31 \\
\hline 19 & 1.40 & 0 & 0 & 0 & .04 & 0 & .01 & 0 & 0 & 0 & 0 & 0 \\
\hline 20 & .02 & 0 & 0 & 0 & 2.62 & 0 & 0 & 0 & 0 & 0 & 0 & .31 \\
\hline 21 & .05 & 0 & 0 & 0 & .23 & 0 & 0 & 0 & 0 & 0 & 0 & .80 \\
\hline 22 & .63 & 0 & .06 & 0 & .01 & .18 & .03 & 0 & 0 & 0 & 0 & 0 \\
\hline 23 & 1.12 & 0 & .40 & 0 & 0 & .01 & .04 & 0 & 0 & 0 & .01 & 0 \\
\hline 24 & 1.63 & 0 & .01 & 0 & .01 & 0 & 0 & 0 & 0 & 0 & .01 & 0 \\
\hline 25 & .05 & 0 & 0 & .21 & 0 & .14 & 0 & 0 & 0 & 0 & 0 & 0 \\
\hline 26 & .01 & .88 & 0 & .03 & .28 & 0 & 0 & .02 & .29 & 0 & 0 & .24 \\
\hline 27 & .04 & 0 & .01 & 0 & 0 & 0 & 0 & 0 & 0 & 0 & 0 & 0 \\
\hline 28 & .09 & 0 & 0 & .02 & .01 & 0 & 0 & 0 & .02 & 0 & 0 & 0 \\
\hline 29 & .01 & 0 & .10 & .01 & -- & 0 & 0 & 0 & 0 & 0 & 0 & 0 \\
\hline 30 & 0 & 0 & .14 & 0 & -- & 0 & 0 & 0 & 0 & 0 & .06 & 0 \\
\hline 31 & .01 & -- & 0 & 0 & -- & 0 & -- & 0 & -- & 0 & .12 & -- \\
\hline Total & 8.89 & 2.92 & 3.90 & 1.73 & 3.82 & .71 & .11 & .04 & 7.55 & 4.79 & .75 & 3.67 \\
\hline
\end{tabular}


Table 5. Daily rainfall at site 4 (USGS station 08167353, Unnamed tributary Honey Creek site 2T), Honey Creek State Natural Area, Comal County, Texas.

[In inches; --, not collected or computed]

\begin{tabular}{|c|c|c|c|c|c|c|c|c|c|c|c|c|}
\hline \multicolumn{13}{|c|}{ Water year October 2001 to September 2002 daily values } \\
\hline Day & Oct. & Nov. & Dec. & Jan. & Feb. & Mar. & Apr. & May & June & July & Aug. & Sept. \\
\hline 1 & 0 & 0 & 0.10 & 0 & 0 & 0.04 & 0 & 0 & 0 & 6.21 & 0 & -- \\
\hline 2 & 0 & 0 & 1.23 & 0 & 0 & .01 & 0 & 0 & 0 & 5.18 & 0 & -- \\
\hline 3 & 0 & 0 & .07 & 0 & 0 & 0 & 0 & 0 & 0 & 2.60 & 0 & -- \\
\hline 4 & 0 & 0 & .01 & .11 & .01 & 0 & 0 & 0 & 0 & 1.86 & 0 & -- \\
\hline 5 & 0 & 0 & .01 & .50 & .56 & 0 & 0 & 0 & .09 & 1.97 & 0 & -- \\
\hline 6 & 0 & 0 & 0 & 0 & 0 & 0 & .24 & 0 & 0 & -- & 0 & -- \\
\hline 7 & 0 & 0 & .01 & .01 & .01 & 0 & 1.03 & 0 & 0 & -- & 0 & -- \\
\hline 8 & 0 & .02 & 1.75 & 0 & 0 & .01 & .07 & 0 & 0 & -- & -- & -- \\
\hline 9 & .05 & .11 & 0 & 0 & 0 & 0 & 0 & 0 & 0 & -- & -- & -- \\
\hline 10 & 0 & 0 & 0 & 0 & 0 & 0 & 0 & 0 & 0 & -- & -- & -- \\
\hline 11 & 2.24 & 0 & .51 & 0 & 0 & 0 & 0 & 0 & 0 & -- & -- & -- \\
\hline 12 & 1.34 & 0 & .02 & 0 & 0 & 0 & 0 & 0 & 0 & -- & -- & -- \\
\hline 13 & .69 & 0 & .02 & 0 & 0 & 0 & 0 & 1.21 & 0 & -- & -- & -- \\
\hline 14 & 0 & .68 & .01 & 0 & 0 & 0 & 0 & 0 & 0 & -- & -- & -- \\
\hline 15 & 0 & 6.14 & .20 & 0 & 0 & 0 & 0 & 0 & .07 & -- & -- & -- \\
\hline 16 & 0 & .01 & .04 & 0 & 0 & 0 & .09 & 0 & .11 & -- & -- & -- \\
\hline 17 & 0 & .08 & 0 & 0 & 0 & 0 & .01 & .03 & 0 & -- & -- & -- \\
\hline 18 & 0 & 0 & 0 & 0 & 0 & .05 & 0 & 0 & 0 & -- & -- & -- \\
\hline 19 & 0 & .03 & 0 & .01 & .12 & .80 & 0 & 0 & 0 & 0 & -- & -- \\
\hline 20 & 0 & .02 & 0 & 0 & 0 & .03 & 0 & 0 & 0 & 0 & -- & -- \\
\hline 21 & 0 & .01 & .01 & 0 & 0 & 0 & 0 & 0 & 0 & 0 & -- & -- \\
\hline 22 & 0 & 0 & 0 & .01 & 0 & 0 & 0 & 0 & 0 & 0 & -- & -- \\
\hline 23 & 0 & 0 & .01 & 0 & 0 & 0 & 0 & 0 & 0 & 0 & -- & -- \\
\hline 24 & 0 & 0 & 0 & .27 & 0 & 0 & 0 & 0 & 0 & 0 & -- & -- \\
\hline 25 & 0 & 0 & .01 & 0 & 0 & 0 & .01 & 0 & 0 & 0 & -- & -- \\
\hline 26 & 0 & 0 & 0 & 0 & 0 & 0 & .01 & .10 & 0 & 0 & -- & -- \\
\hline 27 & 0 & 0 & 0 & 0 & 0 & 0 & 0 & 0 & .02 & 0 & -- & -- \\
\hline 28 & 0 & .03 & 0 & 0 & .01 & 0 & 0 & 1.21 & .03 & 0 & -- & -- \\
\hline 29 & 0 & .16 & .01 & 0 & -- & 0 & 0 & 0 & .16 & 0 & -- & -- \\
\hline 30 & 0 & 0 & 0 & 0 & -- & 1.64 & 0 & 0 & 4.17 & 0 & -- & -- \\
\hline 31 & 0 & -- & 0 & .13 & -- & 0 & -- & 0 & -- & 0 & -- & -- \\
\hline Total & 4.32 & 7.29 & 4.02 & 1.04 & .71 & 2.58 & 1.46 & 2.55 & 4.65 & -- & -- & -- \\
\hline
\end{tabular}


Table 5. Daily rainfall at site 4 (USGS station 08167353, Unnamed tributary Honey Creek site 2T), Honey Creek State Natural Area, Comal County, Texas-Continued.

Water year October 2002 to September 2003 daily values

\begin{tabular}{|c|c|c|c|c|c|c|c|c|c|c|c|c|}
\hline Day & Oct. & Nov. & Dec. & Jan. & Feb. & Mar. & Apr. & May & June & July & Aug. & Sept. \\
\hline 1 & -- & -- & -- & -- & -- & -- & -- & -- & 0 & 0 & 0 & 0.01 \\
\hline 2 & -- & -- & -- & -- & -- & -- & -- & -- & .69 & .01 & 0 & 0 \\
\hline 3 & -- & -- & -- & -- & -- & -- & -- & -- & 0 & .01 & 0 & 0 \\
\hline 4 & -- & -- & -- & -- & -- & -- & -- & -- & .98 & .18 & 0 & 0 \\
\hline 5 & -- & -- & -- & -- & -- & -- & -- & -- & .94 & 1.16 & 0 & .06 \\
\hline 6 & -- & -- & -- & -- & -- & -- & -- & -- & .04 & 1.14 & 0 & .01 \\
\hline 7 & -- & -- & -- & -- & -- & -- & -- & -- & 0 & .17 & 0 & 0 \\
\hline 8 & -- & -- & -- & -- & -- & -- & -- & -- & 0 & .24 & 0 & 0 \\
\hline 9 & -- & -- & -- & -- & -- & -- & -- & -- & 0 & 0 & 0 & 0 \\
\hline 10 & -- & -- & -- & -- & -- & -- & -- & -- & .30 & 0 & .15 & 0 \\
\hline 11 & -- & -- & -- & -- & -- & -- & -- & -- & 0 & 0 & .07 & .73 \\
\hline 12 & -- & -- & -- & -- & -- & -- & -- & -- & 0 & 0 & .28 & .39 \\
\hline 13 & -- & -- & -- & -- & -- & -- & -- & -- & 1.69 & 0 & 0 & 0 \\
\hline 14 & -- & -- & -- & -- & -- & -- & -- & -- & .01 & 0 & .02 & .55 \\
\hline 15 & -- & -- & -- & -- & -- & -- & -- & 0 & .57 & .06 & 0 & 0 \\
\hline 16 & -- & -- & -- & -- & -- & -- & -- & 0 & .01 & .45 & 0 & 0 \\
\hline 17 & -- & -- & -- & -- & -- & -- & -- & 0 & 0 & 0 & 0 & .01 \\
\hline 18 & -- & -- & -- & -- & -- & -- & -- & 0 & 0 & 0 & 0 & .30 \\
\hline 19 & -- & -- & -- & -- & -- & -- & -- & 0 & 0 & 0 & 0 & 0 \\
\hline 20 & -- & -- & -- & -- & -- & -- & -- & 0 & 0 & 0 & 0 & .25 \\
\hline 21 & -- & -- & -- & -- & -- & -- & -- & 0 & 0 & 0 & 0 & .69 \\
\hline 22 & -- & -- & -- & -- & -- & -- & -- & 0 & 0 & 0 & 0 & 0 \\
\hline 23 & -- & -- & -- & -- & -- & -- & -- & 0 & 0 & 0 & .04 & 0 \\
\hline 24 & -- & -- & -- & -- & -- & -- & -- & 0 & 0 & 0 & 0 & 0 \\
\hline 25 & -- & -- & -- & -- & -- & -- & -- & 0 & 0 & 0 & 0 & 0 \\
\hline 26 & -- & -- & -- & -- & -- & -- & -- & 0 & .18 & 0 & 0 & .21 \\
\hline 27 & -- & -- & -- & -- & -- & -- & -- & 0 & 0 & 0 & 0 & 0 \\
\hline 28 & -- & -- & -- & -- & -- & -- & -- & 0 & .10 & 0 & 0 & 0 \\
\hline 29 & -- & -- & -- & -- & -- & -- & -- & 0 & .01 & 0 & 0 & 0 \\
\hline 30 & -- & -- & -- & -- & -- & -- & -- & 0 & 0 & 0 & .20 & -- \\
\hline 31 & -- & -- & -- & -- & -- & -- & -- & 0 & -- & 0 & .12 & -- \\
\hline Total & -- & -- & -- & -- & -- & -- & -- & -- & 5.52 & 3.42 & .88 & -- \\
\hline
\end{tabular}


Table 6. Daily mean streamflow at site 2 (USGS station 08167347, Unnamed tributary Honey Creek site 1C), Honey Creek State Natural Area, Comal County, Texas.

[In cubic feet per second; --, not collected or computed]

\begin{tabular}{|c|c|c|c|c|c|c|c|c|c|c|c|c|}
\hline \multicolumn{13}{|c|}{ Water year October 2001 to September 2002 daily mean values } \\
\hline Day & Oct. & Nov. & Dec. & Jan. & Feb. & Mar. & Apr. & May & June & July & Aug. & Sept. \\
\hline 1 & 0 & 0 & 0 & 0 & 0 & 0 & 0 & 0 & 0 & 8.3 & 0 & 0 \\
\hline 2 & 0 & 0 & 0 & 0 & 0 & 0 & 0 & 0 & 0 & 11 & 0 & 0 \\
\hline 3 & 0 & 0 & .04 & 0 & 0 & 0 & 0 & 0 & 0 & 6.8 & 0 & 0 \\
\hline 4 & 0 & 0 & 0 & 0 & 0 & 0 & 0 & 0 & 0 & 4.4 & 0 & 0 \\
\hline 5 & 0 & 0 & 0 & 0 & 0 & 0 & 0 & 0 & 0 & 7.4 & 0 & 0 \\
\hline 6 & 0 & 0 & 0 & 0 & 0 & 0 & 0 & 0 & 0 & .62 & 0 & 0 \\
\hline 7 & 0 & 0 & 0 & 0 & 0 & 0 & 0 & 0 & 0 & .19 & 0 & 0 \\
\hline 8 & 0 & 0 & 2.1 & 0 & 0 & 0 & 0 & 0 & 0 & .04 & 0 & 0 \\
\hline 9 & 0 & 0 & .13 & 0 & 0 & 0 & 0 & 0 & 0 & .07 & 0 & 0 \\
\hline 10 & 0 & 0 & .06 & 0 & 0 & 0 & 0 & 0 & 0 & .02 & 0 & 0 \\
\hline 11 & .03 & 0 & .28 & 0 & 0 & 0 & 0 & 0 & 0 & 0 & 0 & 0 \\
\hline 12 & .12 & 0 & .13 & 0 & 0 & 0 & 0 & 0 & 0 & 0 & 0 & 0 \\
\hline 13 & 2.1 & 0 & .01 & 0 & 0 & 0 & 0 & 0 & 0 & 0 & 0 & 0 \\
\hline 14 & 0 & 0 & 0 & 0 & 0 & 0 & 0 & 0 & 0 & 1.8 & 0 & 0 \\
\hline 15 & 0 & 11 & 0 & 0 & 0 & 0 & 0 & 0 & 0 & .71 & 0 & 0 \\
\hline 16 & 0 & .28 & 0 & 0 & 0 & 0 & 0 & 0 & 0 & .17 & 0 & 0 \\
\hline 17 & 0 & .12 & 0 & 0 & 0 & 0 & 0 & 0 & 0 & .18 & 0 & 0 \\
\hline 18 & 0 & .03 & 0 & 0 & 0 & 0 & 0 & 0 & 0 & .08 & 0 & 0 \\
\hline 19 & 0 & 0 & 0 & 0 & 0 & 0 & 0 & 0 & 0 & 0 & 0 & 0 \\
\hline 20 & 0 & 0 & 0 & 0 & 0 & 0 & 0 & 0 & 0 & 0 & 0 & 0 \\
\hline 21 & 0 & 0 & 0 & 0 & 0 & 0 & 0 & 0 & 0 & 0 & 0 & 0 \\
\hline 22 & 0 & 0 & 0 & 0 & 0 & 0 & 0 & 0 & 0 & 0 & 0 & 0 \\
\hline 23 & 0 & 0 & 0 & 0 & 0 & 0 & 0 & 0 & 0 & 0 & 0 & 0 \\
\hline 24 & 0 & 0 & 0 & 0 & 0 & 0 & 0 & 0 & 0 & 0 & 0 & 0 \\
\hline 25 & 0 & 0 & 0 & 0 & 0 & 0 & 0 & 0 & 0 & 0 & 0 & 0 \\
\hline 26 & 0 & 0 & 0 & 0 & 0 & 0 & 0 & 0 & 0 & 0 & 0 & 0 \\
\hline 27 & 0 & 0 & 0 & 0 & 0 & 0 & 0 & 0 & 0 & 0 & 0 & 0 \\
\hline 28 & 0 & 0 & 0 & 0 & 0 & 0 & 0 & 0 & 0 & 0 & 0 & 0 \\
\hline 29 & 0 & 0 & 0 & 0 & -- & 0 & 0 & 0 & 0 & 0 & 0 & 0 \\
\hline 30 & 0 & 0 & 0 & 0 & -- & .03 & 0 & 0 & .58 & 0 & 0 & 0 \\
\hline 31 & 0 & -- & 0 & 0 & -- & 0 & -- & 0 & -- & 0 & 0 & -- \\
\hline Total & 2.25 & 11.43 & 2.75 & 0 & 0 & .03 & 0 & 0 & .58 & 41.78 & 0 & 0 \\
\hline Mean & .07 & .38 & .09 & 0 & 0 & 0 & 0 & 0 & .02 & 1.35 & 0 & 0 \\
\hline Maximum & 2.1 & 11 & 2.1 & 0 & 0 & .03 & 0 & 0 & .58 & 11 & 0 & 0 \\
\hline Minimum & 0 & 0 & 0 & 0 & 0 & 0 & 0 & 0 & 0 & 0 & 0 & 0 \\
\hline Acre-feet & 4.5 & 23 & 5.5 & 0 & 0 & .06 & 0 & 0 & 1.2 & 83 & 0 & 0 \\
\hline
\end{tabular}


Table 6. Daily mean streamflow at site 2 (USGS station 08167347, Unnamed tributary Honey Creek site 1C), Honey Creek State Natural Area, Comal County, Texas-Continued.

Water year October 2002 to September 2003 daily mean values

\begin{tabular}{|c|c|c|c|c|c|c|c|c|c|c|c|c|}
\hline Day & Oct. & Nov. & Dec. & Jan. & Feb. & Mar. & Apr. & May & June & July & Aug. & Sept. \\
\hline 1 & 0 & 0 & 0 & 0 & 0 & ${ }^{1} 0$ & ${ }^{1} 0$ & ${ }^{1} 0$ & ${ }^{1} 0$ & ${ }^{1} 0$ & ${ }^{1} 0$ & 0 \\
\hline 2 & 0 & .18 & 0 & 0 & 0 & ${ }^{1} 0$ & ${ }^{1} 0$ & ${ }^{1} 0$ & ${ }^{1} 0$ & ${ }^{1} 0$ & ${ }^{1} 0$ & 0 \\
\hline 3 & 0 & .16 & 0 & 0 & 0 & ${ }^{1} 0$ & ${ }^{1} 0$ & ${ }^{1} 0$ & ${ }^{1} 0$ & ${ }^{1} 0$ & ${ }^{1} 0$ & 0 \\
\hline 4 & 0 & .55 & 0 & 0 & 0 & ${ }^{1} 0$ & ${ }^{1} 0$ & ${ }^{1} 0$ & ${ }^{1} 0$ & ${ }^{1} 0$ & ${ }^{1} 0$ & 0 \\
\hline 5 & 0 & .21 & 0 & 0 & 0 & ${ }^{1} 0$ & ${ }^{1} 0$ & ${ }^{1} 0$ & ${ }^{1} 0$ & ${ }^{1} 0$ & 0 & 0 \\
\hline 6 & 0 & .04 & 0 & 0 & 0 & ${ }^{1} 0$ & ${ }^{1} 0$ & ${ }^{1} 0$ & ${ }^{1} 0$ & ${ }^{1} .02$ & 0 & 0 \\
\hline 7 & 0 & 0 & 0 & 0 & 0 & ${ }^{1} 0$ & ${ }^{1} 0$ & ${ }^{1} 0$ & ${ }^{1} 0$ & ${ }^{1} 0$ & 0 & 0 \\
\hline 8 & .19 & 0 & 0 & 0 & 0 & ${ }^{1} 0$ & ${ }^{1} 0$ & ${ }^{1} 0$ & ${ }^{1} 0$ & ${ }^{1} 0$ & 0 & 0 \\
\hline 9 & 0 & 0 & .64 & 0 & 0 & ${ }^{1} 0$ & ${ }^{1} 0$ & ${ }^{1} 0$ & ${ }^{1} 0$ & ${ }^{1} 0$ & 0 & 0 \\
\hline 10 & 0 & 0 & .04 & 0 & 0 & ${ }^{1} 0$ & ${ }^{1} 0$ & ${ }^{1} 0$ & ${ }^{1} 0$ & ${ }^{1} 0$ & 0 & 0 \\
\hline 11 & 0 & 0 & 0 & 0 & 0 & ${ }^{1} 0$ & ${ }^{1} 0$ & ${ }^{1} 0$ & ${ }^{1} 0$ & ${ }^{1} 0$ & 0 & 0 \\
\hline 12 & 0 & 0 & ${ }^{1} .29$ & ${ }^{1} 0$ & 0 & ${ }^{1} 0$ & ${ }^{1} 0$ & ${ }^{1} 0$ & ${ }^{1} 0$ & ${ }^{1} 0$ & 0 & 0 \\
\hline 13 & 0 & 0 & ${ }^{1} .11$ & ${ }^{1} 0$ & 0 & ${ }^{1} 0$ & ${ }^{1} 0$ & ${ }^{1} 0$ & ${ }^{1} .15$ & ${ }^{1} 0$ & 0 & 0 \\
\hline 14 & 0 & 0 & ${ }^{1} .02$ & 0 & 0 & ${ }^{1} 0$ & ${ }^{1} 0$ & ${ }^{1} 0$ & ${ }^{1} .01$ & ${ }^{1} 0$ & 0 & 0 \\
\hline 15 & 0 & 0 & ${ }^{1} 0$ & 0 & 0 & ${ }^{1} 0$ & ${ }^{1} 0$ & ${ }^{1} 0$ & ${ }^{1} 0$ & ${ }^{1} 0$ & 0 & 0 \\
\hline 16 & 0 & 0 & ${ }^{1} 0$ & 0 & 0 & ${ }^{1} 0$ & ${ }^{1} 0$ & ${ }^{1} 0$ & ${ }^{1} 0$ & ${ }^{1} 0$ & 0 & 0 \\
\hline 17 & 0 & 0 & 0 & 0 & 0 & ${ }^{1} 0$ & ${ }^{1} 0$ & ${ }^{1} 0$ & ${ }^{1} 0$ & ${ }^{1} 0$ & 0 & 0 \\
\hline 18 & 0 & 0 & 0 & 0 & 0 & ${ }^{1} 0$ & ${ }^{1} 0$ & ${ }^{1} 0$ & ${ }^{1} 0$ & ${ }^{1} 0$ & 0 & 0 \\
\hline 19 & .05 & 0 & 0 & 0 & 0 & ${ }^{1} 0$ & ${ }^{1} 0$ & ${ }^{1} 0$ & ${ }^{1} 0$ & ${ }^{1} 0$ & 0 & 0 \\
\hline 20 & 0 & 0 & 0 & 0 & $1_{2.0}$ & ${ }^{1} 0$ & ${ }^{1} 0$ & ${ }^{1} 0$ & ${ }^{1} 0$ & ${ }^{1} 0$ & 0 & ${ }^{1} 0$ \\
\hline 21 & 0 & 0 & 0 & 0 & ${ }^{1} .10$ & ${ }^{1} 0$ & ${ }^{1} 0$ & ${ }^{1} 0$ & ${ }^{1} 0$ & ${ }^{1} 0$ & 0 & ${ }^{1} 0$ \\
\hline 22 & .02 & 0 & 0 & 0 & ${ }^{1} .02$ & ${ }^{1} 0$ & ${ }^{1} 0$ & ${ }^{1} 0$ & ${ }^{1} 0$ & ${ }^{1} 0$ & 0 & ${ }^{1} 0$ \\
\hline 23 & .73 & 0 & 0 & 0 & ${ }^{1} 0$ & ${ }^{1} 0$ & ${ }^{1} 0$ & ${ }^{1} 0$ & ${ }^{1} 0$ & ${ }^{1} 0$ & 0 & ${ }^{1} 0$ \\
\hline 24 & 2.6 & 0 & 0 & 0 & ${ }^{1} 0$ & ${ }^{1} 0$ & ${ }^{1} 0$ & ${ }^{1} 0$ & ${ }^{1} 0$ & ${ }^{1} 0$ & 0 & ${ }^{1} 0$ \\
\hline 25 & .55 & 0 & 0 & 0 & ${ }^{1} 0$ & ${ }^{1} 0$ & ${ }^{1} 0$ & ${ }^{1} 0$ & ${ }^{1} 0$ & ${ }^{1} 0$ & 0 & ${ }^{1} 0$ \\
\hline 26 & .24 & .03 & 0 & 0 & ${ }^{1} 0$ & ${ }^{1} 0$ & ${ }^{1} 0$ & ${ }^{1} 0$ & ${ }^{1} 0$ & ${ }^{1} 0$ & 0 & ${ }^{1} 0$ \\
\hline 27 & .12 & 0 & 0 & 0 & ${ }^{1} 0$ & ${ }^{1} 0$ & ${ }^{1} 0$ & ${ }^{1} 0$ & ${ }^{1} 0$ & ${ }^{1} 0$ & 0 & ${ }^{1} 0$ \\
\hline 28 & .03 & 0 & 0 & 0 & ${ }^{1} 0$ & ${ }^{1} 0$ & ${ }^{1} 0$ & ${ }^{1} 0$ & ${ }^{1} 0$ & ${ }^{1} 0$ & 0 & ${ }^{1} 0$ \\
\hline 29 & 0 & 0 & 0 & 0 & -- & ${ }^{1} 0$ & ${ }^{1} 0$ & ${ }^{1} 0$ & ${ }^{1} 0$ & ${ }^{1} 0$ & 0 & ${ }^{1} 0$ \\
\hline 30 & 0 & 0 & 0 & 0 & -- & ${ }^{1} 0$ & ${ }^{1} 0$ & ${ }^{1} 0$ & ${ }^{1} 0$ & ${ }^{1} 0$ & 0 & ${ }^{1} 0$ \\
\hline 31 & 0 & -- & 0 & 0 & -- & ${ }^{1} 0$ & -- & ${ }^{1} 0$ & -- & ${ }^{1} 0$ & 0 & -- \\
\hline Total & 4.53 & 1.17 & 1.10 & 0 & 2.12 & 0 & 0 & 0 & .16 & .02 & 0 & 0 \\
\hline Mean & .15 & .04 & .04 & 0 & .08 & 0 & 0 & 0 & .01 & 0 & 0 & 0 \\
\hline Maximum & 2.6 & .55 & .64 & 0 & 2.0 & 0 & 0 & 0 & .15 & .02 & 0 & 0 \\
\hline Minimum & 0 & 0 & 0 & 0 & 0 & 0 & 0 & 0 & 0 & 0 & 0 & 0 \\
\hline Acre-feet & 9.0 & 2.3 & 2.2 & 0 & 4.2 & 0 & 0 & 0 & .3 & .04 & 0 & 0 \\
\hline
\end{tabular}

${ }^{1}$ Estimated. 
Table 7. Daily mean streamflow at site 3 (USGS station 08167350, Unnamed tributary Honey Creek site 1T), Honey Creek State Natural Area, Comal County, Texas.

[In cubic feet per second; --, not collected or computed]

\begin{tabular}{|c|c|c|c|c|c|c|c|c|c|c|c|c|}
\hline \multicolumn{13}{|c|}{ Water year October 2001 to September 2002 daily mean values } \\
\hline Day & Oct. & Nov. & Dec. & Jan. & Feb. & Mar. & Apr. & May & June & July & Aug. & Sept. \\
\hline 1 & 0 & 0 & 0 & 0 & 0 & 0 & 0 & 0 & 0 & 10 & 0 & 0 \\
\hline 2 & 0 & 0 & 0 & 0 & 0 & 0 & 0 & 0 & 0 & 17 & 0 & 0 \\
\hline 3 & 0 & 0 & .01 & 0 & 0 & 0 & 0 & 0 & 0 & 5.6 & 0 & 0 \\
\hline 4 & 0 & 0 & 0 & 0 & 0 & 0 & 0 & 0 & 0 & 2.7 & 0 & 0 \\
\hline 5 & 0 & 0 & 0 & 0 & 0 & 0 & 0 & 0 & 0 & 6.1 & 0 & 0 \\
\hline 6 & 0 & 0 & 0 & 0 & 0 & 0 & 0 & 0 & 0 & .23 & 0 & 0 \\
\hline 7 & 0 & 0 & 0 & 0 & 0 & 0 & 0 & 0 & 0 & .07 & 0 & 0 \\
\hline 8 & 0 & 0 & 1.1 & 0 & 0 & 0 & 0 & 0 & 0 & .02 & 0 & 0 \\
\hline 9 & 0 & 0 & .10 & 0 & 0 & 0 & 0 & 0 & 0 & .04 & 0 & 0 \\
\hline 10 & 0 & 0 & .02 & 0 & 0 & 0 & 0 & 0 & 0 & .01 & 0 & 0 \\
\hline 11 & 0 & 0 & .14 & 0 & 0 & 0 & 0 & 0 & 0 & 0 & 0 & 0 \\
\hline 12 & .01 & 0 & .09 & 0 & 0 & 0 & 0 & 0 & 0 & 0 & 0 & 0 \\
\hline 13 & .58 & 0 & 0 & 0 & 0 & 0 & 0 & 0 & 0 & 0 & 0 & 0 \\
\hline 14 & 0 & 0 & 0 & 0 & 0 & 0 & 0 & 0 & 0 & .31 & 0 & 0 \\
\hline 15 & 0 & 9.7 & 0 & 0 & 0 & 0 & 0 & 0 & 0 & .56 & 0 & 0 \\
\hline 16 & 0 & .26 & 0 & 0 & 0 & 0 & 0 & 0 & 0 & .11 & 0 & 0 \\
\hline 17 & 0 & .05 & 0 & 0 & 0 & 0 & 0 & 0 & 0 & .09 & 0 & 0 \\
\hline 18 & 0 & 0 & 0 & 0 & 0 & 0 & 0 & 0 & 0 & .03 & 0 & 0 \\
\hline 19 & 0 & 0 & 0 & 0 & 0 & 0 & 0 & 0 & 0 & 0 & 0 & 0 \\
\hline 20 & 0 & 0 & 0 & 0 & 0 & 0 & 0 & 0 & 0 & 0 & 0 & 0 \\
\hline 21 & 0 & 0 & 0 & 0 & 0 & 0 & 0 & 0 & 0 & 0 & 0 & 0 \\
\hline 22 & 0 & 0 & 0 & 0 & 0 & 0 & 0 & 0 & 0 & 0 & 0 & 0 \\
\hline 23 & 0 & 0 & 0 & 0 & 0 & 0 & 0 & 0 & 0 & 0 & 0 & 0 \\
\hline 24 & 0 & 0 & 0 & 0 & 0 & 0 & 0 & 0 & 0 & 0 & 0 & 0 \\
\hline 25 & 0 & 0 & 0 & 0 & 0 & 0 & 0 & 0 & 0 & 0 & 0 & 0 \\
\hline 26 & 0 & 0 & 0 & 0 & 0 & 0 & 0 & 0 & 0 & 0 & 0 & 0 \\
\hline 27 & 0 & 0 & 0 & 0 & 0 & 0 & 0 & 0 & 0 & 0 & 0 & 0 \\
\hline 28 & 0 & 0 & 0 & 0 & 0 & 0 & 0 & 0 & 0 & 0 & 0 & 0 \\
\hline 29 & 0 & 0 & 0 & 0 & -- & 0 & 0 & 0 & 0 & 0 & 0 & 0 \\
\hline 30 & 0 & 0 & 0 & 0 & -- & 0 & 0 & 0 & .01 & 0 & 0 & 0 \\
\hline 31 & 0 & -- & 0 & 0 & -- & 0 & -- & 0 & -- & 0 & 0 & -- \\
\hline Total & .59 & 1.01 & 1.46 & 0 & 0 & 0 & 0 & 0 & .01 & 42.87 & 0 & 0 \\
\hline Mean & .02 & .33 & .05 & 0 & 0 & 0 & 0 & 0 & 0 & 1.38 & 0 & 0 \\
\hline Maximum & .58 & 9.7 & 1.1 & 0 & 0 & 0 & 0 & 0 & .01 & 17 & 0 & 0 \\
\hline Minimum & 0 & 0 & 0 & 0 & 0 & 0 & 0 & 0 & 0 & 0 & 0 & 0 \\
\hline Acre-feet & 1.2 & 20 & 2.9 & 0 & 0 & 0 & 0 & 0 & .02 & 85 & 0 & 0 \\
\hline
\end{tabular}


Table 7. Daily mean streamflow at site 3 (USGS station 08167350, Unnamed tributary Honey Creek site 1T), Honey Creek State Natural Area, Comal County, Texas-Continued.

Water year October 2002 to September 2003 daily mean values

\begin{tabular}{|c|c|c|c|c|c|c|c|c|c|c|c|c|}
\hline Day & Oct. & Nov. & Dec. & Jan. & Feb. & Mar. & Apr. & May & June & July & Aug. & Sept \\
\hline 2 & 0 & .08 & 0 & 0 & 0 & 0 & 0 & 0 & 0 & 0 & 0 & 0 \\
\hline 3 & 0 & .06 & 0 & 0 & 0 & 0 & 0 & 0 & 0 & 0 & 0 & 0 \\
\hline 4 & 0 & .30 & 0 & 0 & 0 & 0 & 0 & 0 & 0 & 0 & 0 & 0 \\
\hline 5 & 0 & .10 & 0 & 0 & 0 & 0 & 0 & 0 & 0 & 0 & 0 & 0 \\
\hline 6 & 0 & 0 & 0 & 0 & 0 & 0 & 0 & 0 & 0 & 0 & 0 & 0 \\
\hline 7 & 0 & 0 & 0 & 0 & 0 & 0 & 0 & 0 & 0 & 0 & 0 & 0 \\
\hline 8 & .14 & 0 & 0 & 0 & 0 & 0 & 0 & 0 & 0 & 0 & 0 & 0 \\
\hline 9 & 0 & 0 & .09 & 0 & 0 & 0 & 0 & 0 & 0 & 0 & 0 & 0 \\
\hline 12 & 0 & 0 & .15 & 0 & 0 & 0 & 0 & 0 & 0 & 0 & 0 & 0 \\
\hline 13 & 0 & 0 & .01 & 0 & 0 & 0 & 0 & 0 & .05 & 0 & 0 & 0 \\
\hline 14 & 0 & 0 & 0 & 0 & 0 & 0 & 0 & 0 & 0 & 0 & 0 & 0 \\
\hline 15 & 0 & 0 & 0 & 0 & 0 & 0 & 0 & 0 & 0 & 0 & 0 & 0 \\
\hline 16 & 0 & 0 & 0 & 0 & 0 & 0 & 0 & 0 & 0 & 0 & 0 & 0 \\
\hline 17 & 0 & 0 & 0 & 0 & 0 & 0 & 0 & 0 & 0 & 0 & 0 & 0 \\
\hline 18 & 0 & 0 & 0 & 0 & 0 & 0 & 0 & 0 & 0 & 0 & 0 & 0 \\
\hline 19 & 0 & 0 & 0 & 0 & 0 & 0 & 0 & 0 & 0 & 0 & 0 & 0 \\
\hline 25 & .23 & 0 & 0 & 0 & 0 & 0 & 0 & 0 & 0 & 0 & 0 & 0 \\
\hline 26 & .07 & 0 & 0 & 0 & 0 & 0 & 0 & 0 & 0 & 0 & 0 & 0 \\
\hline 27 & .01 & 0 & 0 & 0 & 0 & 0 & 0 & 0 & 0 & 0 & 0 & 0 \\
\hline 28 & 0 & 0 & 0 & 0 & 0 & 0 & 0 & 0 & 0 & 0 & 0 & 0 \\
\hline 29 & 0 & 0 & 0 & 0 & -- & 0 & 0 & 0 & 0 & 0 & 0 & 0 \\
\hline 30 & 0 & 0 & 0 & 0 & -- & 0 & 0 & 0 & 0 & 0 & 0 & 0 \\
\hline 31 & 0 & -- & 0 & 0 & -- & 0 & -- & 0 & -- & 0 & 0 & -- \\
\hline Total & 2.53 & .54 & .25 & 0 & 1.06 & 0 & 0 & 0 & .05 & 0 & 0 & 0 \\
\hline Mean & .08 & .02 & .01 & 0 & .04 & 0 & 0 & 0 & 0 & 0 & 0 & 0 \\
\hline Maximum & 1.7 & .30 & .15 & 0 & 1.0 & 0 & 0 & 0 & .05 & 0 & 0 & 0 \\
\hline Minimum & 0 & 0 & 0 & 0 & 0 & 0 & 0 & 0 & 0 & 0 & 0 & 0 \\
\hline Acre-feet & 5.0 & 1.1 & .5 & 0 & 2.1 & 0 & 0 & 0 & .1 & 0 & 0 & 0 \\
\hline
\end{tabular}


Table 8. Daily mean streamflow at site 4 (USGS station 08167353, Unnamed tributary Honey Creek site 2T), Honey Creek State Natural Area, Comal County, Texas.

[In cubic feet per second; --, not collected or computed]

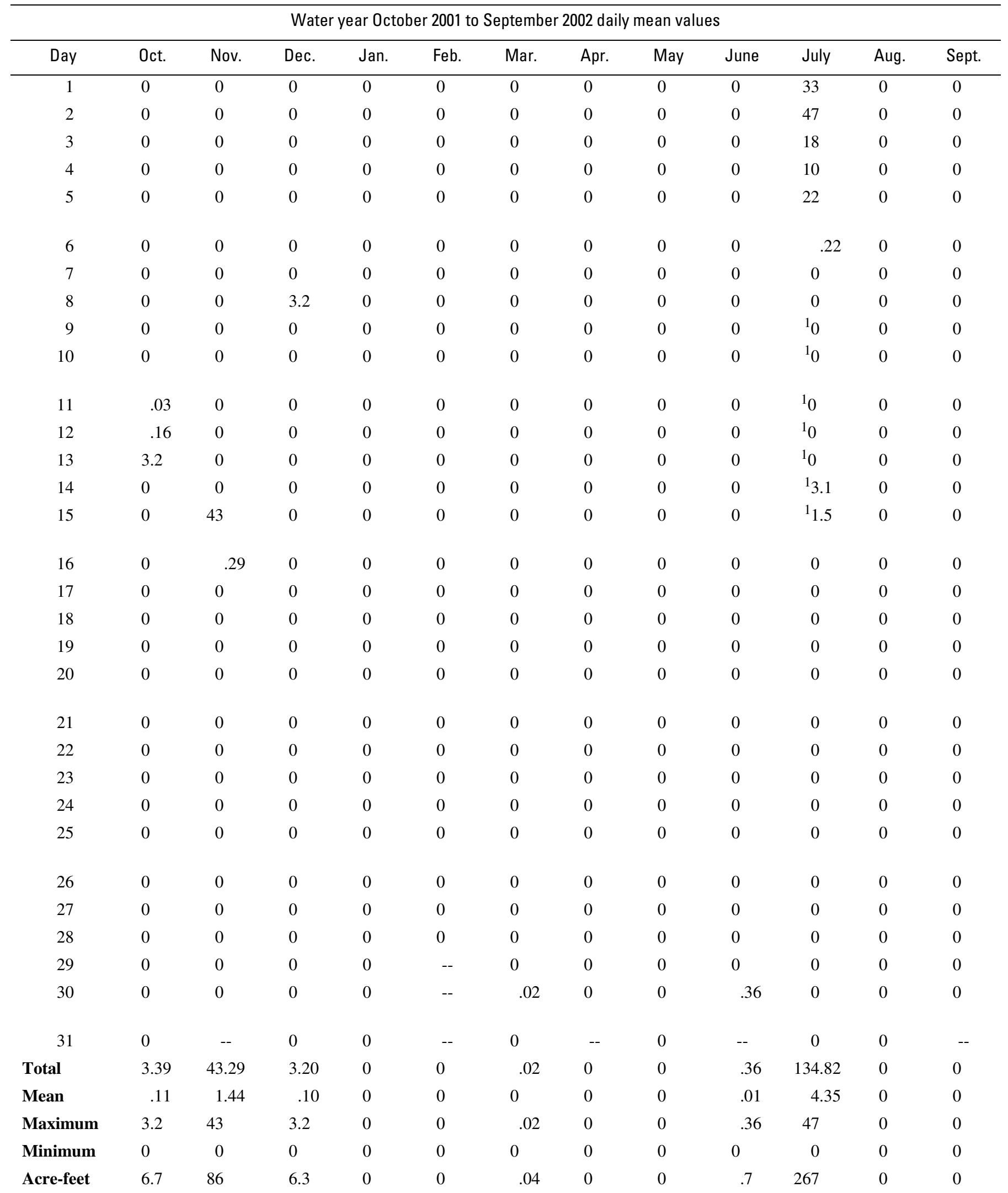


Table 8. Daily mean streamflow at site 4 (USGS station 08167353, Unnamed tributary Honey Creek site 2T), Honey Creek State Natural Area, Comal County, Texas-Continued.

\begin{tabular}{|c|c|c|c|c|c|c|c|c|c|c|c|c|}
\hline \multicolumn{13}{|c|}{ Water year October 2002 to September 2003 daily mean values } \\
\hline Day & 0 ct. & Nov. & Dec. & Jan. & Feb. & Mar. & Apr. & May & June & July & Aug. & Sept. \\
\hline 1 & 0 & 0 & 0 & 0 & 0 & 0 & 0 & 0 & 0 & 0 & 0 & 0 \\
\hline 2 & 0 & 0 & 0 & 0 & 0 & 0 & 0 & 0 & 0 & 0 & 0 & 0 \\
\hline 3 & 0 & 0 & 0 & 0 & 0 & 0 & 0 & 0 & 0 & 0 & 0 & 0 \\
\hline 4 & 0 & .12 & 0 & 0 & 0 & 0 & 0 & 0 & 0 & 0 & 0 & 0 \\
\hline 5 & 0 & 0 & 0 & 0 & 0 & 0 & 0 & 0 & .01 & 0 & 0 & 0 \\
\hline 6 & 0 & 0 & 0 & 0 & 0 & 0 & 0 & 0 & 0 & .08 & 0 & 0 \\
\hline 7 & 0 & 0 & 0 & 0 & 0 & 0 & 0 & 0 & 0 & 0 & 0 & 0 \\
\hline 8 & .08 & 0 & 0 & 0 & 0 & 0 & 0 & 0 & 0 & 0 & 0 & 0 \\
\hline 9 & 0 & 0 & .25 & 0 & 0 & 0 & 0 & 0 & 0 & 0 & 0 & 0 \\
\hline 10 & 0 & 0 & 0 & 0 & 0 & 0 & 0 & 0 & 0 & 0 & 0 & 0 \\
\hline 11 & 0 & 0 & 0 & 0 & 0 & 0 & 0 & 0 & 0 & 0 & 0 & 0 \\
\hline 12 & 0 & 0 & .08 & 0 & 0 & 0 & 0 & 0 & 0 & 0 & 0 & 0 \\
\hline 13 & 0 & 0 & 0 & 0 & 0 & 0 & 0 & 0 & .29 & 0 & 0 & 0 \\
\hline 14 & 0 & 0 & 0 & 0 & 0 & 0 & 0 & 0 & .01 & 0 & 0 & 0 \\
\hline 15 & 0 & 0 & 0 & 0 & 0 & 0 & 0 & 0 & .01 & 0 & 0 & 0 \\
\hline 16 & 0 & 0 & 0 & 0 & 0 & 0 & 0 & 0 & 0 & 0 & 0 & 0 \\
\hline 17 & 0 & 0 & 0 & 0 & 0 & 0 & 0 & 0 & 0 & 0 & 0 & 0 \\
\hline 18 & 0 & 0 & 0 & 0 & 0 & 0 & 0 & 0 & 0 & 0 & 0 & 0 \\
\hline 19 & .05 & 0 & 0 & 0 & 0 & 0 & 0 & 0 & 0 & 0 & 0 & 0 \\
\hline 20 & 0 & 0 & 0 & 0 & 3.4 & 0 & 0 & 0 & 0 & 0 & 0 & 0 \\
\hline 21 & 0 & 0 & 0 & 0 & 0 & 0 & 0 & 0 & 0 & 0 & 0 & 0 \\
\hline 22 & 0 & 0 & 0 & 0 & 0 & 0 & 0 & 0 & 0 & 0 & 0 & 0 \\
\hline 23 & .44 & 0 & 0 & 0 & 0 & 0 & 0 & 0 & 0 & 0 & 0 & 0 \\
\hline 24 & 3.7 & 0 & 0 & 0 & 0 & 0 & 0 & 0 & 0 & 0 & 0 & 0 \\
\hline 25 & .02 & 0 & 0 & 0 & 0 & 0 & 0 & 0 & 0 & 0 & 0 & 0 \\
\hline 26 & 0 & 0 & 0 & 0 & 0 & 0 & 0 & 0 & 0 & 0 & 0 & 0 \\
\hline 27 & 0 & 0 & 0 & 0 & 0 & 0 & 0 & 0 & 0 & 0 & 0 & 0 \\
\hline 28 & 0 & 0 & 0 & 0 & 0 & 0 & 0 & 0 & 0 & 0 & 0 & 0 \\
\hline 29 & 0 & 0 & 0 & 0 & -- & 0 & 0 & 0 & 0 & 0 & 0 & 0 \\
\hline 30 & 0 & 0 & 0 & 0 & -- & ${ }^{1} 0$ & 0 & 0 & 0 & 0 & 0 & 0 \\
\hline 31 & 0 & -- & 0 & 0 & -- & 0 & -- & 0 & -- & 0 & 0 & -- \\
\hline Total & 4.29 & .12 & .33 & 0 & 3.40 & 0 & 0 & 0 & .32 & .08 & 0 & 0 \\
\hline Mean & .14 & 0 & .01 & 0 & .12 & 0 & 0 & 0 & .01 & 0 & 0 & 0 \\
\hline Maximum & 3.7 & .12 & .25 & 0 & 3.4 & 0 & 0 & 0 & .29 & .08 & 0 & 0 \\
\hline Minimum & 0 & 0 & 0 & 0 & 0 & 0 & 0 & 0 & 0 & 0 & 0 & 0 \\
\hline Acre-feet & 8.5 & .2 & .7 & 0 & 6.7 & 0 & 0 & 0 & .6 & .2 & 0 & 0 \\
\hline
\end{tabular}

${ }^{1}$ Estimated. 
Table 9. Daily evapotranspiration at site 6 (USGS station 295104098285900, Honey Creek reference evapotranspiration), Honey Creek State Natural Area, Comal County, Texas.

[In inches; --, not collected or computed]

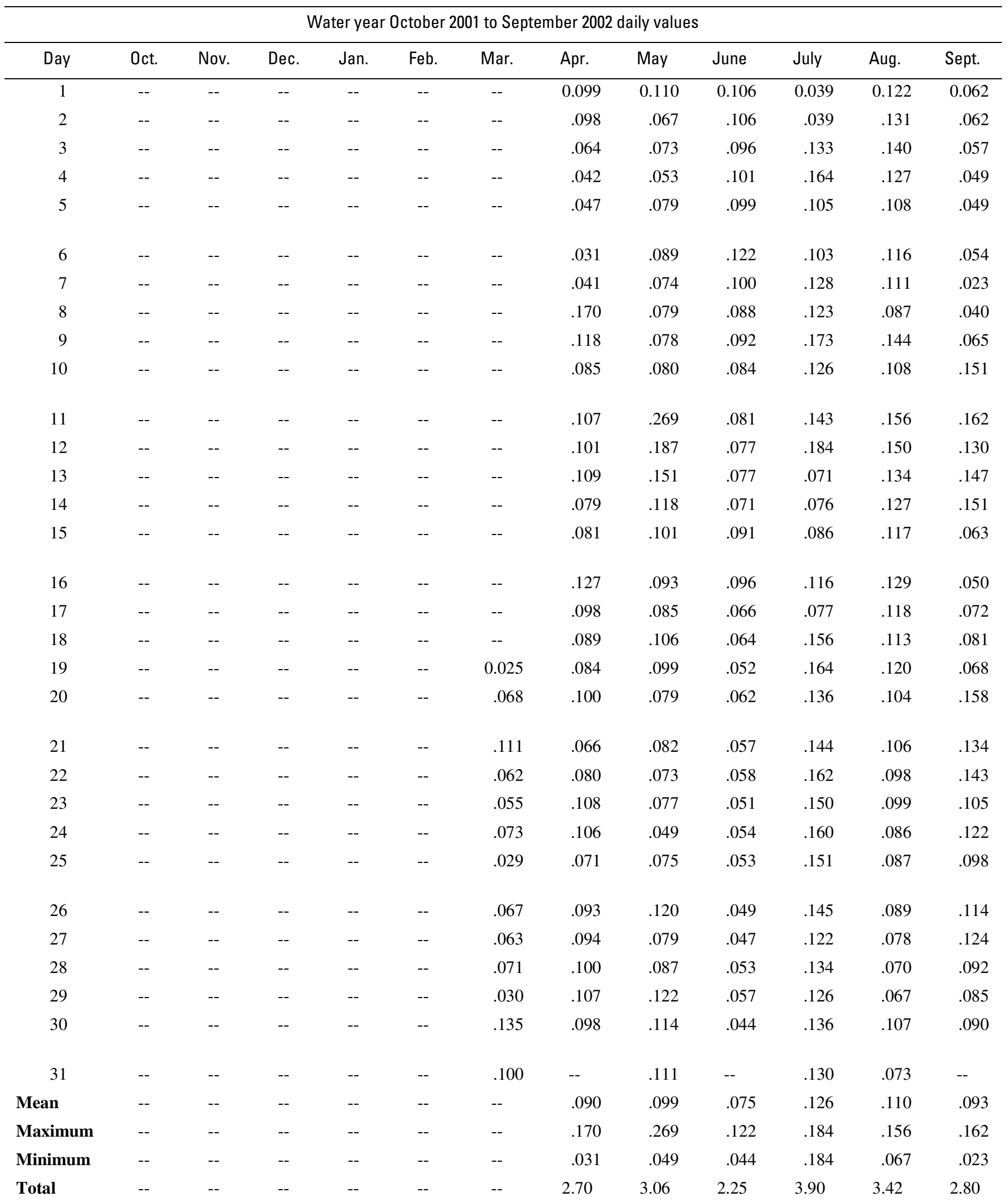


Table 9. Daily evapotranspiration at site 6 (USGS station 295104098285900, Honey Creek reference evapotranspiration), Honey Creek State Natural Area, Comal County, Texas-Continued.

\begin{tabular}{|c|c|c|c|c|c|c|c|c|c|c|c|c|}
\hline \multicolumn{13}{|c|}{ Water year October 2002 to September 2003 daily values } \\
\hline Day & 0ct. & Nov. & Dec. & Jan. & Feb. & Mar. & Apr. & May & June & July & Aug. & Sept. \\
\hline 1 & 0.111 & 0.037 & 0.047 & 0.058 & 0.051 & -- & -- & -- & -- & -- & -- & 0.050 \\
\hline 2 & .088 & .022 & .029 & .046 & .022 & -- & -- & -- & -- & -- & -- & .040 \\
\hline 3 & .091 & .018 & .022 & .047 & .069 & 0.038 & -- & -- & -- & -- & -- & .049 \\
\hline 4 & .096 & .024 & .047 & .040 & .048 & .052 & -- & -- & -- & -- & -- & .051 \\
\hline 5 & .085 & .108 & .030 & .040 & .020 & .025 & -- & -- & -- & -- & -- & .066 \\
\hline 6 & .082 & .087 & .040 & .025 & .044 & .086 & -- & -- & -- & -- & -- & .041 \\
\hline 7 & .067 & .069 & .018 & .043 & .019 & .085 & -- & -- & -- & -- & -- & .037 \\
\hline 8 & .052 & .069 & .011 & .046 & .017 & .043 & -- & -- & -- & -- & -- & .030 \\
\hline 9 & .093 & .064 & .015 & .055 & .081 & .064 & -- & -- & -- & -- & -- & .038 \\
\hline 10 & .068 & .085 & .029 & .044 & .068 & .077 & -- & -- & -- & -- & -- & .030 \\
\hline 11 & .078 & .079 & .032 & .020 & .047 & .021 & -- & -- & -- & -- & -- & .111 \\
\hline 12 & .076 & .081 & .051 & .016 & .018 & .027 & -- & -- & -- & -- & -- & .105 \\
\hline 13 & .047 & .056 & .074 & .014 & .021 & .098 & -- & -- & -- & -- & -- & .081 \\
\hline 14 & .039 & .055 & .050 & .044 & .027 & .089 & -- & -- & -- & -- & -- & .110 \\
\hline 15 & .105 & .050 & .031 & .025 & .063 & .044 & -- & -- & -- & -- & -- & .101 \\
\hline 16 & .098 & .057 & .040 & .060 & .056 & .079 & -- & -- & -- & -- & -- & .071 \\
\hline 17 & .083 & .054 & .034 & .034 & .058 & .051 & -- & -- & -- & -- & -- & .072 \\
\hline 18 & .030 & .050 & .045 & .041 & .036 & .120 & -- & -- & -- & -- & -- & .083 \\
\hline 19 & .050 & .069 & .066 & .031 & .025 & .103 & -- & -- & -- & -- & -- & .050 \\
\hline 20 & .071 & .066 & .052 & .044 & .025 & .017 & -- & -- & -- & -- & -- & .034 \\
\hline 21 & .022 & .067 & .042 & .056 & .019 & -- & -- & -- & -- & -- & -- & .131 \\
\hline 22 & .061 & .055 & .031 & .040 & .110 & -- & -- & -- & -- & -- & -- & .105 \\
\hline 23 & .084 & .050 & .034 & .034 & .091 & -- & -- & -- & -- & -- & -- & .073 \\
\hline 24 & .024 & .034 & .048 & .021 & .023 & -- & -- & -- & -- & -- & -- & .115 \\
\hline 25 & .036 & .031 & .030 & .015 & -- & -- & -- & -- & -- & -- & -- & .085 \\
\hline 26 & .028 & .019 & .026 & .012 & -- & -- & -- & -- & -- & -- & -- & .097 \\
\hline 27 & .042 & .036 & .052 & .020 & -- & -- & -- & -- & -- & -- & -- & .146 \\
\hline 28 & .021 & .044 & .042 & .019 & -- & -- & -- & -- & -- & -- & -- & .113 \\
\hline 29 & .106 & .041 & .012 & .058 & -- & -- & -- & -- & -- & -- & -- & .104 \\
\hline 30 & .079 & .050 & .033 & .028 & -- & -- & -- & -- & -- & -- & -- & .103 \\
\hline 31 & .045 & -- & .071 & .058 & -- & -- & -- & -- & -- & -- & -- & -- \\
\hline Mean & .070 & .050 & .040 & .040 & -- & -- & -- & -- & -- & -- & -- & .080 \\
\hline Maximum & .111 & .108 & .074 & .060 & -- & -- & -- & -- & -- & -- & -- & .146 \\
\hline Minimum & .021 & .018 & .011 & .014 & -- & -- & -- & -- & -- & -- & -- & .030 \\
\hline Total & 2.06 & 1.63 & 1.18 & 1.14 & -- & -- & -- & -- & -- & -- & -- & 2.32 \\
\hline
\end{tabular}


Table 10. Daily evapotranspiration at site 7 (USGS station 295102098283200, Honey Creek treatment evapotranspiration), Honey Creek State Natural Area, Comal County, Texas.

[In inches; --, not collected or computed]

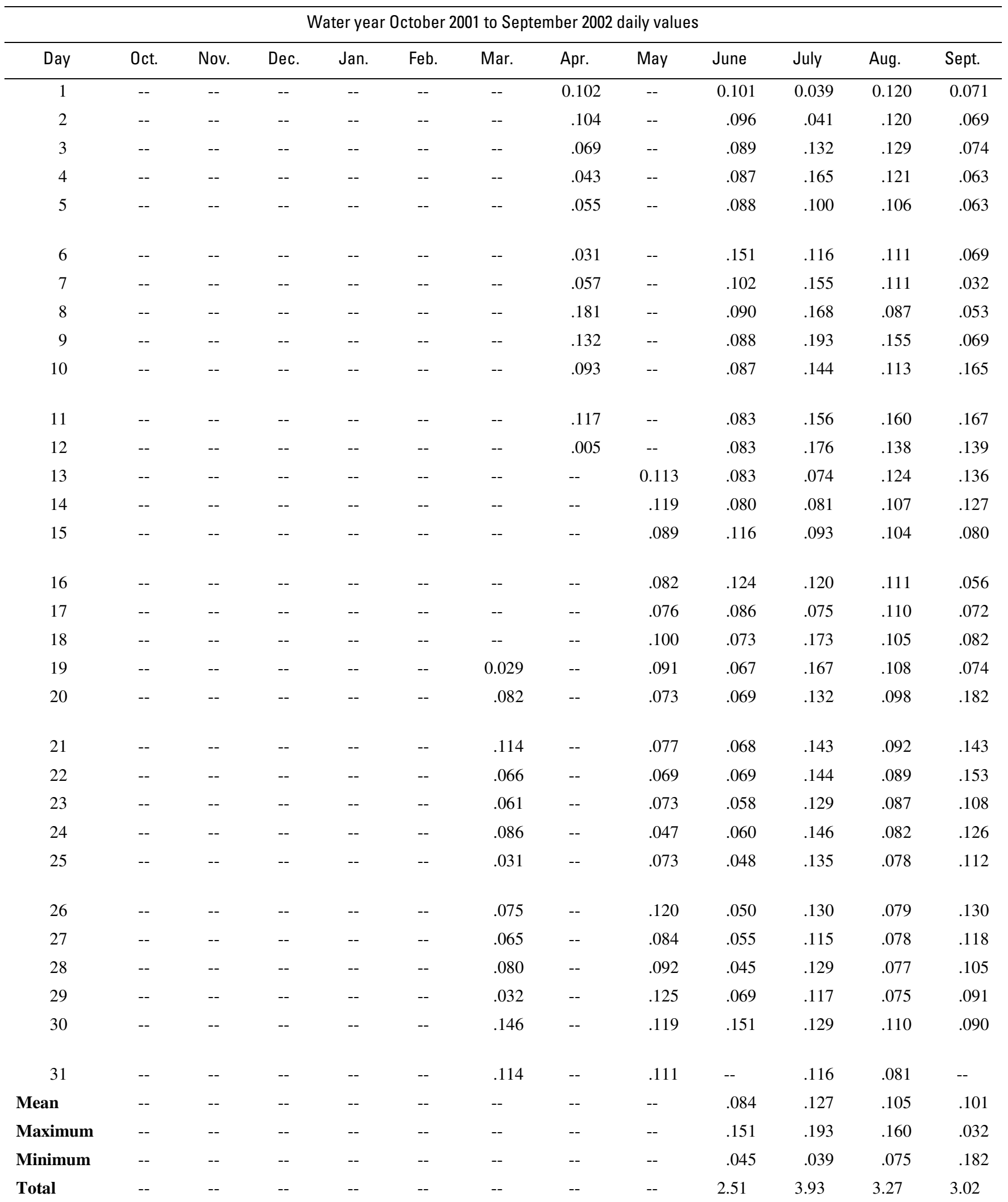


Table 10. Daily evapotranspiration at site 7 (USGS station 295102098283200, Honey Creek treatment evapotranspiration), Honey Creek State Natural Area, Comal County, Texas-Continued.

Water year October 2002 to September 2003 daily values

\begin{tabular}{|c|c|c|c|c|c|c|c|c|c|c|c|c|}
\hline Day & 0ct. & Nov. & Dec. & Jan. & Feb. & Mar. & Apr. & May & June & July & Aug. & Sept. \\
\hline 1 & 0.089 & 0.041 & 0.049 & 0.064 & 0.056 & -- & -- & -- & -- & -- & -- & 0.044 \\
\hline 2 & .080 & .021 & .030 & .046 & .028 & -- & -- & -- & -- & -- & -- & .031 \\
\hline 3 & .079 & .009 & .022 & .051 & .072 & 0.056 & -- & -- & -- & -- & -- & .047 \\
\hline 4 & .095 & -- & .047 & .043 & .053 & .052 & -- & -- & -- & -- & -- & .062 \\
\hline 5 & .085 & .116 & .032 & .044 & .017 & .029 & -- & -- & -- & -- & -- & .078 \\
\hline 6 & .083 & .090 & .047 & .029 & .055 & .098 & -- & -- & -- & -- & -- & .040 \\
\hline 7 & .068 & .072 & .021 & .042 & .021 & .099 & -- & -- & -- & -- & -- & .028 \\
\hline 8 & .049 & .074 & .012 & .052 & .018 & .043 & -- & -- & -- & -- & -- & .029 \\
\hline 9 & .104 & .073 & .023 & .055 & .089 & .071 & -- & -- & -- & -- & -- & .031 \\
\hline 10 & .072 & .089 & .029 & .043 & .066 & .083 & -- & -- & -- & -- & -- & .024 \\
\hline 11 & .085 & .078 & .034 & .021 & .051 & .018 & -- & -- & -- & -- & -- & .104 \\
\hline 12 & .080 & .076 & .048 & .017 & .018 & .027 & -- & -- & -- & -- & -- & 109 \\
\hline 13 & .047 & .057 & .076 & .015 & .024 & .104 & -- & -- & -- & -- & -- & .081 \\
\hline 14 & .039 & .059 & .053 & .050 & .038 & .096 & -- & -- & -- & -- & -- & .113 \\
\hline 15 & .110 & .051 & .042 & .027 & .064 & .049 & -- & -- & -- & -- & -- & .098 \\
\hline 16 & .088 & .056 & .047 & .062 & .061 & .082 & -- & -- & -- & -- & -- & .060 \\
\hline 17 & .088 & .055 & .038 & .036 & .062 & .051 & -- & -- & -- & -- & -- & .064 \\
\hline 18 & .032 & .050 & .049 & .048 & .039 & .123 & -- & -- & -- & -- & -- & .078 \\
\hline 19 & .057 & .061 & .069 & .036 & .029 & .117 & -- & -- & -- & -- & -- & .050 \\
\hline 20 & .077 & .061 & .060 & .049 & .031 & .049 & -- & -- & -- & -- & -- & .047 \\
\hline 21 & .028 & .060 & .050 & .060 & .019 & -- & -- & -- & -- & -- & -- & .136 \\
\hline 22 & .072 & .053 & .038 & .040 & .113 & -- & -- & -- & -- & -- & -- & .106 \\
\hline 23 & .087 & .050 & .037 & .034 & .098 & -- & -- & -- & -- & -- & -- & .061 \\
\hline 24 & .033 & .034 & .053 & .020 & .023 & -- & -- & -- & -- & -- & -- & .098 \\
\hline 25 & .037 & .031 & .031 & .015 & -- & -- & -- & -- & -- & -- & -- & .078 \\
\hline 26 & .027 & .024 & .027 & .017 & -- & -- & -- & -- & -- & -- & -- & .097 \\
\hline 27 & .042 & .038 & .049 & .021 & -- & -- & -- & -- & -- & -- & -- & .148 \\
\hline 28 & .021 & .046 & .050 & .018 & -- & -- & -- & -- & -- & -- & -- & .113 \\
\hline 29 & .104 & .045 & .012 & .058 & -- & -- & -- & -- & -- & -- & -- & .098 \\
\hline 30 & .088 & .053 & .038 & .031 & -- & -- & -- & -- & -- & -- & -- & .093 \\
\hline 31 & .047 & -- & .063 & .058 & -- & -- & -- & -- & -- & -- & -- & -- \\
\hline Mean & .068 & .056 & .041 & .039 & -- & -- & -- & -- & -- & -- & -- & .075 \\
\hline Maximum & .110 & .116 & .076 & .064 & -- & -- & -- & -- & -- & -- & -- & .148 \\
\hline Minimum & .021 & .009 & .012 & .015 & -- & -- & -- & -- & -- & -- & -- & .024 \\
\hline Total & 2.09 & 1.62 & 1.28 & 1.20 & -- & -- & -- & -- & -- & -- & -- & 2.25 \\
\hline
\end{tabular}


Table 11. Water-quality sample site, date, and type, Honey Creek State Natural Area, Comal County, Texas.

[X, sample collected; --, sample not collected]

Rainfall water quality

\begin{tabular}{rrrrr}
\hline \multirow{2}{*}{ Date } & \multicolumn{4}{c}{ Sample type } \\
\cline { 2 - 5 } & Field property & Major ion & Nutrient & Isotope \\
\hline & Site 5 (USGS station 295108098283201 Honey Creek rainfall water quality) \\
$10 / 11 / 2001$ & $\mathrm{X}$ & $\mathrm{X}$ & $\mathrm{X}$ & $\mathrm{X}$ \\
$11 / 15 / 2001$ & $\mathrm{X}$ & $\mathrm{X}$ & $\mathrm{X}$ & $\mathrm{X}$ \\
$06 / 30 / 2002$ & $\mathrm{X}$ & $\mathrm{X}$ & $\mathrm{X}$ & $\mathrm{X}$ \\
\hline
\end{tabular}

Stormflow water quality

\begin{tabular}{|c|c|c|c|c|c|c|}
\hline \multirow{2}{*}{ Date } & \multicolumn{6}{|c|}{ Sample type } \\
\hline & Field property & Major ion & Nutrient & Pesticide & Isotope & Sediment \\
\hline \multicolumn{7}{|c|}{ Site 2 (USGS station 08167347 Unnamed tributary Honey Creek site 1C) } \\
\hline 08/30/2001 & $\mathrm{X}$ & $\mathrm{X}$ & $\mathrm{X}$ & $\mathrm{X}$ & $\mathrm{X}$ & $\mathrm{X}$ \\
\hline 10/11/2001 & $\mathrm{X}$ & $\mathrm{X}$ & $\mathrm{X}$ & -- & $\mathrm{X}$ & $\mathrm{X}$ \\
\hline $11 / 15-16 / 2001$ & $\mathrm{X}$ & $\mathrm{X}$ & $\mathrm{X}$ & -- & $\mathrm{X}$ & $\mathrm{X}$ \\
\hline 03/30/2002 & -- & -- & -- & -- & -- & $\mathrm{X}$ \\
\hline 04/07/2002 & $\mathrm{X}$ & $\mathrm{X}$ & $\mathrm{X}$ & -- & $\mathrm{X}$ & -- \\
\hline 06/30/2002 & $\mathrm{X}$ & $\mathrm{x}$ & $\mathrm{X}$ & -- & $\mathrm{X}$ & $\mathrm{X}$ \\
\hline \multicolumn{7}{|c|}{ Site 3 (USGS station 08167350 Unnamed tributary Honey Creek site 1T) } \\
\hline 08/30/2001 & $\mathrm{X}$ & $\mathrm{X}$ & $\mathrm{X}$ & $\mathrm{X}$ & $\mathrm{X}$ & $\mathrm{X}$ \\
\hline $10 / 11 / 2001$ & $\mathrm{X}$ & $\mathrm{X}$ & $\mathrm{X}$ & -- & $\mathrm{X}$ & $\mathrm{X}$ \\
\hline 06/30/2002 & $\mathrm{X}$ & $\mathrm{x}$ & $\mathrm{X}$ & -- & $\mathrm{X}$ & $\mathrm{X}$ \\
\hline \multicolumn{7}{|c|}{ Site 4 (USGS station 08167353 Unnamed tributary Honey Creek site 2T) } \\
\hline 08/30/2001 & $\mathrm{X}$ & $\mathrm{X}$ & $\mathrm{X}$ & $\mathrm{X}$ & $\mathrm{X}$ & $\mathrm{X}$ \\
\hline 06/30/2002 & $\mathrm{X}$ & $\mathrm{X}$ & $\mathrm{X}$ & -- & $\mathrm{X}$ & $\mathrm{X}$ \\
\hline
\end{tabular}


Prepared by the USGS Texas Water Science Center:

8027 Exchange Drive

Austin, TX 78754-4733

Information regarding water resources in Texas is available at http: //tx.usgs.gov/ 